January 2014

\title{
Taxing Polygamy: Married Filing Jointly (and Severally?)
}

Samuel D. Brunson

Loyola University Chicago, sbrunson@luc.edu

Follow this and additional works at: https://ecommons.luc.edu/social_justice

Part of the Law Commons

\section{Recommended Citation}

Brunson, Samuel D., "Taxing Polygamy: Married Filing Jointly (and Severally?)" (2014). Social Justice. 6. https://ecommons.luc.edu/social_justice/6

This is brought to you for free and open access by the Centers at Loyola eCommons. It has been accepted for inclusion in Social Justice by an authorized administrator of Loyola eCommons. For more information, please contactecommons@luc.edu. 


\title{
Taxing Polygamy: Married Filing Jointly (and Severally?)
}

\author{
Samuel D. Brunson*
}

\begin{abstract}
The tax law treats married and unmarried taxpayers differently in several respects. Married persons, for example, can file and pay their taxes as a unified taxpayer, with rates that are different than those that apply to unmarried taxpayers. This different treatment of married persons has elicited criticism over the years. Some of the more salient criticisms include that married persons do not necessarily function as an economic unit, that joint filing discourages women from working, and that the various exclusions from the joint filing regime-including gay couples-is unfair.

This Article looks at joint filing through the lens of polygamy. Polygamy stretches joint filing beyond what it can handle: while the current tax rates could accommodate same-sex couples without any substantive changes, applying the current married-filing-jointly tax brackets to polygamous taxpayers would have unjust results. Polygamous marriage is not only quantitatively different than dyadic marriage: it is qualitatively different. Ultimately, I conclude that changing from a joint filing system to a mandatory individual filing system that recognizes marriage for certain purposes would be the fairest and most administrable way to treat marriage. Because most commentators think, however, that eliminating joint filing will not happen in the foreseeable future, the second-best solution would treat the polygamous marriage as a series of dyad, and would split the common spouse's income between each dyad, while accounting for that spouse's reduced income.
\end{abstract}

\section{TABLE OF CONTENTS}

I. Introduction ... 2

\footnotetext{
* Assistant Professor, Loyola University Chicago School of Law. I would like to thank Stephen Black, Elizabeth M. Glazer, David J. Herzig, Nancy J. Knauer, Jeffrey L. Kwall, Noah A. Messing, Anne-Marie Rhodes, Spencer W. Waller, and the participants in the Fourth Annual J. Reuben Clark Law Society Conference and the 2011 Critical Perspectives on Tax Policy Conference at Emory University. I would also like to thank Loyola University Chicago School of Law for its summer research stipend. Additional thanks to Jamie Brunson for her support.
} 


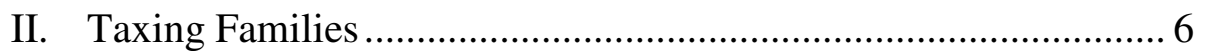

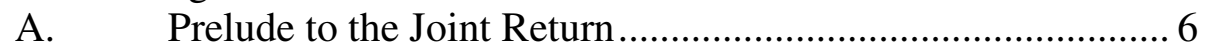

B. Problems With Joint Filing ................................................... 11

III. Non-Traditional Families and the Future of the Joint Return ..... 16

A. Non-Traditional Dyadic Taxpayers....................................... 16

B. Polygamous Taxpayers ……………………...................... 18

IV. Tax Discrimination and Fairness ................................................ 23

A. DOMA and Same-Sex Marriage ……………...................... 26

B. Polygamists and Tax Evasion …………….......................... 30

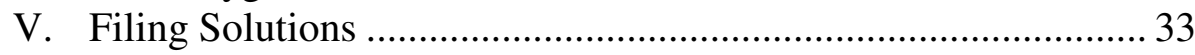

A. Refuse to Recognize Polygamous Marriage ……………...... 37

B. Treat the Entire Polygamous Family As an Economic Unit 39

C. Index Tax Brackets to Family Size ....................................... 40

D. Balkanized Filing …………………………….................. 44

E. Mandatory Individual Filing ................................................. 49

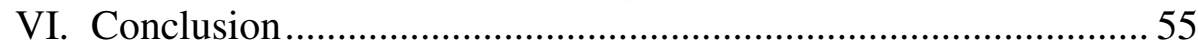

\section{INTRODUCTION}

Overwhelmingly, Americans find polygamy distasteful, if not immoral. ${ }^{1}$ For some, such distaste seems almost visceral, a reaction to what they consider a barbaric and backward practice. ${ }^{2}$ Others point to concrete harms polygamy allegedly causes. For example, polygamy's critics frequently highlight the sexual exploitation of underage girls and the general inequality and abuse women face in polygamous communities to underscore polygamy's immorality. But critics do not end their list of the polygamy's evils with the abuse of women and girls. As they dig deeper into the litany of evils perpetrated by polygamists, critics almost invariably mention a problem far less intuitive: tax evasion. ${ }^{3}$

\footnotetext{
${ }^{1}$ A 2008 Gallup poll found that 90 percent of American adults surveyed considered polygamy immoral. Arland Thornton, The International Fight Against Barbarism: Historical and Comparative Perspectives on Marriage Timing, Consent, and Polygamy, in Modern Polygamy IN THE United States 259, 283 (Cardell K. Jacobson \& Lara Burton, eds., 2011).

${ }^{2}$ See, e.g., id. at 274 ("Mormon polygamy was labeled as Asiatic or oriental barbarism and was viewed not only as a threat to future advancement but as a force for the destruction of thousands of years of European progress.").

${ }^{3}$ See, e.g., Victims of Polygamy Assistance Act of 2008, S. 3313, 110th Cong. § 2(3) ("The crimes perpetrated by [polygamous] organizations include child abuse, domestic violence, welfare fraud, tax evasion, public corruption, witness tampering,
} 
Still, although critics mention tax evasion, nobody has analyzed the tax consequences of polygamy. Instead, the vast majority of academic discussions of polygamy falls into two categories: whether to decriminalize polygamy ${ }^{4}$ and the level (if any) of constitutional protection polygamy should enjoy. ${ }^{5}$ Scholars have ignored questions of whether other generally-applicable laws could apply in their current form if a state legalized polygamous marriages. Recently, however, Professor Adrienne Davis introduced a "new

and transporting victims across State lines.”); Brandon Griggs, Polygamy Czar Forecasts More Prosecutions Soon; Critics: Not Enough Is Being Done, SALT LAKE TRIB., May 12, 2003, at A1 ("Prosecutors also are focusing on tax fraud and abuses of the state's welfare system."); Richard A. Vazquez, Note, The Practice of Polygamy: Legitimate Free Exercise of Religion or Legitimate Public Menace? Revisiting Reynolds in Light of Modern Constitutional Jurisprudence, 5 N.Y.U. J. LEGIS. \& PUB. POL'Y 225, 244 (2001) ("According to anti-polygamy activists, welfare and tax fraud are commonplace in Utah's polygamous communities."); Adrienne D. Davis, Regulating Polygamy: Intimacy, Default Rules, and Bargaining for Equality, 110 ColuM. L. REV. 1955, 1975 (2010) ("Polygamy offends a diverse array of interests . . . [including] those who argue polygamy provides a cover for a range of fraudulent behavior from welfare abuse to tax fraud.")

${ }^{4}$ See, e.g., Shayna M. Sigman, Everything Lawyers Know About Polygamy Is Wrong, 16 CORNELl J.L. \& PUB. POL'Y 101 (2006) (arguing that the criminalization of polygamy is based on incorrect understanding"); Michael Lwin, Big Love: Perry v. Schwarzenegger and Polygamous Marriage, 9 GEO. J.L. \& PUB. POL'Y 393 (2011) (comparing movement to decriminalize polygamy with movements to decriminalize sodomy and marijuana); Maura Strassberg, The Crime of Polygamy, 12 TEMP. PoL. \& CIV. RTS. L. REV. 353 (2003) (arguing that criminalizing polygamy serves the public interest).

See, e.g., Jaime M. Gher, Polygamy and Same-Sex Marriage-Allies or Adversaries Within the Same-Sex Marriage Movement, 14 WM. \& MARY J. OF WOMEN \& L. 559, 581 (2008) ("The strongest arguments in favor of decriminalizing polygamy, however, are constitutional claims for religious freedom, Due Process, and Equal Protection."); Marci A. Hamilton, The First Amendment's Challenge Function and the Confusion in the Supreme Court's Contemporary Free Exercise Jurisprudence, 29 GA. L. REV. 81, 105-10 (discussing Supreme Court's polygamy jurisprudence); Maura Strassberg, Distinctions of Form or Substance: Monogamy, Polygamy, and Same-Sex Marriage, 75 N.C. L. REV. 1501, 1593-94 (1997); Keith E. Sealing, Polygamists Out of the Closet: Statutory and State Prohibitions Against Polygamy Are Unconstitutional Under the Free Exercise Clause, 17 Ga. St. U.L. Rev. 691, 757 (2001) ("Very little effort has been put into the analysis of the current constitutionality of the nineteenth century polygamy cases in light of current trends in the American religious landscape, the modern American family, and First Amendment jurisprudence."); Martin Guggenheim, Texas Polygamy and Child Welfare, 46 Hous. L. REV. 759, 763-64 (2009) (arguing that in light of Lawrence, polygamy may deserve constitutional protection). 
approach" to polygamy scholarship. ${ }^{6}$ She proposes that secondgeneration polygamy questions should ask "whether and how polygamy might be effectively recognized and regulated."7 Professor Davis goes on to propose that the default rules of polygamy could mimic commercial partnership law. ${ }^{8}$

In the spirit of Professor Davis's second-generation polygamy question, this Article represents the first attempt to address polygamous families and the federal income tax. ${ }^{9}$ The legalization and regulation of polygamy provides limited benefits to polygamists if their tax status remains unresolved. Polygamists, like most Americans, must earn income. Furthermore, like most Americans, they will need to calculate and pay taxes on that income. The tax law, however, has no mechanism for dealing with polygamous taxpayers. Though changing the focus of the discussion from whether polygamy oppresses women to how polygamous families can file their taxes seems a descent from the sublime to the banal, paying federal income tax represents one of the few experiences common to nearly all Americans, irrespective of marital status. The tax system, then, represents one legal regime polygamists would need to navigate.

Much of the scholarship that addresses polygamy also addresses same-sex marriage. Both opponents and proponents of polygamy point to growing legal and societal acceptance of homosexuality as paving the way toward legalized polygamy. ${ }^{10}$ The

\footnotetext{
${ }^{6}$ Davis, supra note 3, at 1958.

${ }^{7}$ Id.

${ }^{8}$ Id. at 1959.

${ }^{9}$ This Article will not address whether, as a normative matter, states should legalize polygamy. Rather, it will focus on how to accommodate such a non-traditional family into the joint filing tax regime, and on what the struggle to make a polygamous family fit into the regime tells us about the viability of joint filing. Nonetheless, several people, in reviewing earlier drafts of this Article, have recommended that I lay out my position on the decriminalization and legalization of polygamy. I believe, as a normative matter, that polygamy should be decriminalized, though I find myself agnostic about its legalization. On a personal level, though, I am a romantic, invested in dyadic marriage. See Davis, supra note 3, at 1975 (those offended by polygamy include "romantics invested in the companionate bond that conventional marriage is imagined to engender").

${ }^{10}$ Polygamy advocates in fact point to the Supreme Court's decision in Lawrence as paving the way toward a right to marry, whether or not it actually does so. See Davis, supra note 3, at 1960 ("Others call for full recognition and licensure, frequently invoking Lawrence as a strategic step that sets the stage for recognition of plural marriage alongside gay marriage.").
} 
same-sex marriage scholarship, moreover, has addressed issues of filing and paying taxes. ${ }^{11}$ However, in this area, as in others, a polygamous marriage is not merely dyadic marriage plus. ${ }^{12}$ Without the Defense of Marriage Act ("DOMA"), 13 the tax law could treat opposite-sex and same-sex marriages identically. Although scholars have debated whether marriage should affect tax filing and tax liability, ${ }^{14}$ once there are special rules applicable to married couples, those rules can apply in the same manner to all dyadic marriages.

Polygamous marriage, though, is both quantitatively and qualitatively different than dyadic marriage. As a result, this Article will evaluate how current tax law would treat polygamous spouses. Part II will discuss the provenance joint tax filing in the United States, as well as the current criticisms and defenses of joint filing. Part III will discuss tax issues facing nontraditional dyadic families, including domestic partnerships, civil unions, same-sex marriages, and contrast those with the issues facing polygamous taxpayers. Part IV will discuss how polygamy implicates the fairness of current tax law. Finally, Part V will propose a series of approaches that the tax law could take to accommodate polygamous taxpayers. It will discuss the pros and cons of these several approaches, and will propose two that would make the tax law's treatment of dyadic and polygamous taxpayers more equitable. ${ }^{15}$

\footnotetext{
${ }^{11}$ See infra Section IV.A.

${ }^{12}$ Following Professor Davis, this Article will use "dyadic" to describe any marriage between just two people, whether the same or opposite genders. See id. at 1966 ("Hence, the Article uses the term dyadic marriage, or occasionally conventional marriage, to characterize the current marital legal regime.").

${ }^{13}$ Pub. L. No. 104-199, 110 Stat. 2419 (1996) (codified at 1 U.S.C. § 7). DOMA limits the definition of marriage to a marriage between one man and one woman for all federal purposes. Id.

${ }^{14}$ See infra Section II.B.

${ }^{15}$ In general when talking about polygamy, this Article will assume polygynous (i.e., one man with multiple wives) relationships. Although polyandry (one woman with multiple husbands) exists, polygyny is the most common form of polygamy. Miriam Koktvedgaard Zeitzen, Polygamy: A Cross-Cultural ANAlysis 58 (2008). But the problems and potential solutions discussed in this Article should generally apply to any legalized polygamous marriage.
} 


\section{TAXING FAMILIES}

Marriage complicates the design of a fair and progressive income tax. ${ }^{16}$ Once it acknowledges marriage, a tax regime must determine whether to treat the married couple as a taxpaying unit or whether each individual spouse must pay taxes separately. A fair tax system should include marriage neutrality, income pooling, and progressive tax rates; ${ }^{17}$ unfortunately, as Professor Boris Bittker famously illustrated, these principles conflict with each other, so, in designing a marriage tax, Congress cannot achieve all three goals. ${ }^{18}$

\section{A. Prelude to the Joint Return}

Although the federal income tax currently treats married couples as an appropriate taxpaying unit, throughout its history, the federal income tax has alternated between treating individuals and married couples as that unit. ${ }^{19}$ When Congress originally enacted the federal income tax, it chose the individual as the appropriate taxable unit, ${ }^{20}$ imposing tax on the "net income of every individual." ${ }^{21}$ In spite of the plain language of the statute, the Bureau of Internal Revenue initially "took the position that the 1913 income tax . . . taxed married couples as units." 22 The next year, though, the Treasury Department reversed itself, requiring husbands and wives to file separate returns. $^{23}$ In 1918, the Treasury Department reversed itself again, providing taxpayers an optional joint return that allowed married

\footnotetext{
${ }^{16}$ Samuel D. Brunson, Grown-Up Income Shifting: Yesterday's Kiddie Tax Is Not Enough, 59 U. KANS. L. REV. 457, 468 (2011) ("Marriage throws a wrench into the design of a tax system.").

${ }^{17}$ Jane M. Fraser, The Marriage Tax, 32 MGMT. SCI. 831, 831 (1986). Marriage neutrality means that a couple's tax burden should not change because of marriage or divorce. Income pooling means that a married couple's tax liability should depend only on their combined income, and not on their individual incomes. Progressivity means that higher-income families should pay a higher percentage of their incomes in taxes than lower-income families. Id.

${ }^{18}$ Boris I. Bittker, Federal Income Taxation and the Family, 27 STAN. L. REV. 1389, 1395-96 (1975).

${ }^{19}$ Patricia M. Cain, Taxing Families Fairly, 48 SANTA ClARA L. REV. 805, 807-08 (2008).

${ }^{20}$ Bittker, supra note 18 , at 1400.

${ }^{21}$ Revenue Act of 1913, Section II, A. subdiv. 2., 38 Stat. 114, 166.

${ }^{22}$ Stephanie Hunter McMahon, To Have and to Hold: What Does Love (of Money) Have To Do With Joint Tax Filing, 11 NEV. L.J. 710, 723 (2011).

${ }^{23}$ Cain, supra note 19 , at 808 .
} 
couples to aggregate their income if they desired. ${ }^{24}$ The joint return simplified tax filing for married couples "whose combined income was below the amount that would trigger the surtax rate." ${ }^{25}$ However, when rates significantly increased with the United States' entry into World War I, ${ }^{26}$ filing joint returns became considerably less appealing to high-income taxpayers. ${ }^{27}$ The higher rates caused highincome taxpayers to work harder, when possible, to shift a portion of their income to lower-taxed individuals. ${ }^{28}$

Income-shifting created some risk for the high-income taxpayer, though. To the extent he shifted his income to another person, he risked losing control of that income. In order to maintain control over the income and benefit from it, a high-income taxpayer would need to shift the income to a person over whom he had some control or whom he justifiably trusted. Often, therefore, he shifted his income to his wife or to other family members. ${ }^{29}$

The courts attempted to hold the line against this incomeshifting, finding that a taxpayer "who earns or is otherwise entitled to receive income cannot assign it, for tax purposes, to another taxpayer, even if the transfer is effective under state law." ${ }^{30}$ Ultimately, though, two Supreme Court decisions in this area caused an enormous rift

\footnotetext{
${ }^{24} I d$.

${ }^{25} \mathrm{Id}$.

${ }^{26}$ SteVen A. BAnK, Kirk J. Stark \& Joseph J. Thorndike, WAR AND TAXes 64 (2008) ("Designed to raise $\$ 850$ million from income taxes, the [War Revenue Act] dramatically increased individual surtax rates, with the top rate rising from 13 to 50 percent.").

${ }^{27}$ Cain, supra note 19 , at 809 . In 1918 , a husband and wife who had $\$ 100,000$ of taxable income paid total taxes of $\$ 24,000$ if they filed separate returns reflecting $\$ 50,000$ of income each. If, however, they filed jointly, they owed $\$ 36,500, \$ 12,500$ more than they would have owed filing separately. Dennis J. Ventry, Jr., Saving Seaborn: Ownership Not Marriage as the Basis of Family Taxation, 86 IND. L. REV. 1459, 1469-70 (2011).

${ }^{28}$ Id. For example, a taxpayer in the 35 percent tax bracket would owe taxes of $\$ 700$ on an additional $\$ 2,000$ of income, leaving her with $\$ 1,300$ after taxes. If, however, she could shift half of her income to a taxpayer in the 10 percent tax bracket, she would pay $\$ 350$ of taxes on the $\$ 1,000$ she kept, while the second taxpayer would only pay $\$ 100$ of taxes on his $\$ 1,000$. Collectively, they would keep $\$ 1,550$, reducing their aggregate tax bill by $\$ 250$.

${ }^{29}$ See, e.g., Brunson, supra note 16, at 457-58 ("Congress's principal direct assault on income shifting sought to prevent wealthy parents from unfairly reducing their tax bills by giving some of their didivend-paying stocks and interest-bearing bonds to their children.").

${ }^{30}$ Bittker, supra note 20, at 1400.
} 
between the tax treatment of married couples in common law states and those in community property states. ${ }^{31}$

The first of those cases involved an agreement between $\mathrm{Mr}$. and Mrs. Earl. In 1901, the couple entered into a contract stipulating that they owned all current and future property and income as joint tenants with a right of survivorship. ${ }^{32}$ Because his wife had a contractual right to half of Mr. Earl's income, the Earls argued that he should only report and pay taxes on half of his income, while his wife should pay taxes on the other half. ${ }^{33}$ The Supreme Court acknowledged both the validity of the contract and its effect under California law. ${ }^{34}$ Nonetheless, the Court determined that the Revenue Act of 1918 both could and did tax salaries "to those who earned them." ${ }^{35}$ Fruit, in the Court's analogy, could not be "attributed to a different tree from that on which [it] grew." 36

That same year, though, the Supreme Court weakened its fruitfrom-the-tree analogy in a second case involving an attempt to shift income from the earner to his spouse. In 1927, H.G. Seaborn and his wife lived in Washington, a community property state. ${ }^{37}$ That year, their income included his salary, dividends, interest, and gains on the sale of property, including real estate that was held solely in his name. ${ }^{38}$ They filed separate returns for their 1927 taxable year, each reporting half of the collective income and claiming half of the deductions. While technically the law vested Mrs. Seaborn with half of the property, the Commissioner of Internal Revenue argued that Mr. Seaborn had so much control over the property that, as long as

\footnotetext{
${ }^{31}$ Lily Kahng, One Is the Loneliest Number: The Single Taxpayer in a Joint Return World, 61 HASTINGS L.J. 651, 653 (2010).

${ }^{32}$ Lucas v. Earl, 281 U.S. 111, 113-14 (1930).

${ }^{33} I d$. at 113 . Although spouses with dissimilar incomes may have tried to evade the higher tax rates by contractually dividing their income, see James M. Puckett, Rethinking Tax Priorities: Marriage Neutrality, Children, and Contemporary Families, 78 U. CIN. L. REV. 1409, 1413 (2010), the Earls had not entered into this contract to avoid taxes. In 1901, the 16th Amendment and the federal income tax were still twelve years away. Rather, their agreement was likely an estate-planning device. Patricia A. Cain, The Story of Earl, in TAX StORIEs 305, 314-15 (Paul L. Caron, ed., Foundation Press, 2d ed. 2009).

${ }^{34}$ Earl, 281 U.S. at 114.

${ }^{35} \mathrm{Id}$.

${ }^{36} \mathrm{Id}$. at 115.

${ }^{37}$ Poe v. Seaborn, 282 U.S. 101, 108 (1930).

${ }^{38} \mathrm{Id}$. at 108-09.
} 
the marriage lasted, all of the income belonged to him. ${ }^{39}$ As a result, the Commissioner claimed, Mr. Seaborn should have declared all of his income on his return. ${ }^{40}$ The Supreme Court held that, because state law treated the income as belonging to the community of $\mathrm{Mr}$. and Mrs. Seaborn, they were correct to file separate returns, each declaring half of the couple's income. ${ }^{41}$

The Seaborn decision created a rift between states. Married couples in community property states could file separate returns, splitting their income and potentially paying less in taxes than a similarly-situated married couple in a common law state. Moreover, as a result of the Earl decision, couples in common-law states had no way to replicate this intra-spousal income-shifting. Following Seaborn, the Treasury Department tried to prevent income-shifting. Although initially unsuccessful, in 1941, Treasury convinced the House Ways and Means Committee to recommend that Congress enact a mandatory joint return for married couples. ${ }^{42}$ As part of the Revenue Act of 1941, a married couple would have paid taxes on its consolidated income at the rate of a single person with the same amount of income. ${ }^{43}$ The reaction to the mandatory joint return threatened to defeat the entire Revenue Act, and President Roosevelt withdrew the provision. ${ }^{44}$ Although Treasury tried again in 1942this time with protection for wives' wages-the provision again failed. $^{45}$

While the federal government tried unsuccessfully to eliminate the disparity between common law and community property states, the states themselves worked to exploit the difference for the benefit of their residents. In order to procure for their married residents the ability to split their income for federal income tax purposes,

\footnotetext{
${ }^{39}$ Id. at 111 .

${ }^{40}$ Id. at 109 .

${ }^{41} I d$. at 118.

${ }^{42}$ Bittker, supra note 20, at 1408.

${ }^{43} I d$. at 1409.

${ }^{44}$ Alice Kessler-Harris, "A Principle of Law but Not of Justice”: Men, Women and the Income Taxes in the United States 1913-1948, 6 S. CAL. REV. L \& WOMEN'S STUDIES 331, 345 (1997). Under Treasury's proposal, most married couples in community property states would pay higher taxes, as would married couples in common law states if both spouses earned income from services or investments. At the same time, two people with separate sources of income would pay more taxes if they married than if they remained single. Bittker, supra note 20, at 1409.

${ }^{45}$ Kessler-Harris, supra note 44 , at 345.
} 
Oklahoma and Oregon enacted legislation allowing married couples to elect into a newly-created community property regime. ${ }^{46}$ The Supreme Court refused to allow these elective laws to alter the tax treatment of married couples, though, saying that, at best, "the present policy of Oklahoma is to permit spouses, by contract, to alter the status which they would otherwise have under the prevailing property system in the State." ${ }^{47}$ The Court held that the Oklahoma statute functioned in essentially the same manner as the contract in Earl, and that such an elective property regime could not prevent the government from taxing the person who earned the income. ${ }^{48}$

In reaction to the Supreme Court's decision, Oklahoma and Oregon amended their community property statutes, making them mandatory. ${ }^{49}$ Hawai'i, Pennsylvania, Michigan, and Nebraska soon followed and, by 1948, New York and Massachusetts had begun to consider enacting community property laws. ${ }^{50}$ The states did not necessarily want to move to community property - a study in New York warned of difficulties in the transition-but without a federal solution, they saw this self-help as necessary. ${ }^{51}$ Still, in spite of its importance to married taxpayers, these moves from common law to community property laws caused "upheaval and uncertainty."

As common law states turned to self-help to achieve tax benefits for their residents, some demanded that the federal law change. In reaction to this lobbying - and buoyed by significant surpluses-Congress enacted the Revenue Act of 1948. ${ }^{53}$ The Revenue Act of 1948 permitted married couples to file jointly and to enjoy a marginal tax bracket twice as large as the bracket applicable to an unmarried taxpayer. ${ }^{54}$ Congress intended for this new joint filing option to equalize the taxation of married couples between common law and community property states and, as such, prevent common law states from enacting community property statutes. ${ }^{55}$

\footnotetext{
${ }^{46}$ Bittker, supra note 20 , at 1411 .

${ }^{47}$ Commissioner v. Harmon, 323 U.S. 44, 46 (1944).

${ }^{48} \mathrm{Id}$. at 47.

${ }^{49}$ Bittker, supra note 20, at 1411-12.

${ }^{50} \mathrm{Id}$. at 1412.

${ }^{51} I d$.

${ }^{52}$ Kahng, supra note 31, at 654.

${ }^{53}$ McMahon, supra note 22, at 736.

${ }_{55}^{54}$ Puckett, supra note 33, at 1414.

${ }^{55} \mathrm{Id}$.
} 
As long as the tax brackets for married couples filing jointly were twice the size of the brackets that applied to individuals, a married couple never paid more in taxes than two unmarried taxpayers with the same income. ${ }^{56}$ To ameliorate the unfairness toward unmarried taxpayers, Congress enacted a new rate schedule for married couples in 1969; a married couple's marginal brackets under the new schedule remained wider than, but not twice as wide as, the brackets of single taxpayers. $^{57}$

\section{B. Problems With Joint Filing}

Introducing joint filing threw a wrench in the design of the tax system, however. A tax system that includes joint filing cannot have progressive tax rates and achieve both marriage and couples neutrality, all reasonable goals of a just tax system. ${ }^{58} \mathrm{~A}$ progressive income tax applies increasingly higher rates of tax as a taxpayer's income increases. ${ }^{59}$ And to the extent that marriage changes the taxpaying unit, a progressive tax cannot escape treating taxpayers differently depending on their marital status. ${ }^{60}$

Joint filing causes three significant departures from marriage and couples neutrality: the singles penalty, the marriage penalty, and the marriage bonus. Each of these departures violates the tax norm of horizontal equity, which holds that taxpayers with similar income should pay a similar amount of taxes. ${ }^{61}$

The singles penalty applies when an unmarried individual has the same income as a married couple. ${ }^{62}$ For example, Susan, an unmarried individual who has taxable income of $\$ 100,000$, and Scott

\footnotetext{
${ }^{56}$ Kahng, supra note 31, at 655.

${ }^{57}$ Bittker, supra note 20, at 1428.

${ }^{58}$ Brunson, supra note 16 , at 469.

${ }^{59}$ Lawrence Zelenak, Marriage and the Income Tax, 67 S. CAL. L. REV. 339, 339 (1994). Although periodically somebody argues for a flat (that is, non-progressive) income tax, even the most committed supporters of a flat tax do not advocate a "true flat-rate tax [that] would tax all income ....,] starting with the first dollar, at the same rate." Barbara H. Fried, The Puzzling Case for Proportionate Taxation, 2 CHAP. L. REV. 157, 160-61 (1998). Americans generally recognize the need for some degree of progressivity in the tax system.

${ }^{60}$ Zelenak, supra note 59, at 339-40.

${ }^{61}$ See, e.g., Richard A. Musgrave, Horizontal Equity, Once More, 43 NAT. TAX. J. 113,113 (1990) ("The call for equity in taxation is generally taken to include a rule of horizontal equity ...., requiring equal treatment of equals, and one of vertical equity ... ., calling for an appropriate differentiation among unequals.").

${ }^{62}$ Kahng, supra note 31 , at 655.
} 
and Stacy, a married couple who each earn $\$ 50,000$. In 2011, Susan would owe \$21,617 in federal income taxes. ${ }^{63}$ Scott and Stacy, on the other hand, would owe just $\$ 17,250$ in taxes, significantly less than Susan. ${ }^{64}$

The marriage penalty comes into play when a married couple pays more taxes than two unmarried individuals with the same taxable income. ${ }^{65}$ The marriage penalty generally comes into play when both spouses earn approximately the same income. ${ }^{66}$ John and Jane, for example, each has $\$ 75,000$ in taxable income. In 2011, if John and Jane are married and file a joint return, their combined income puts them in the 28-percent tax bracket, and they owe $\$ 30,069.50 .^{67}$ If, however, John and Jane had chosen not to marry, each would be in the 25 -percent tax bracket. ${ }^{68}$ Both John and Jane would owe $\$ 14,875$ in taxes, for a combined tax liability of \$29,750. Marriage costs John and Jane an additional $\$ 319.50$ in taxes.

Where spouses' income differs significantly, on the other hand, a married couple may benefit from the marriage bonus. ${ }^{69}$ Imagine Mary, who has taxable income of $\$ 150,000$, and Mark, with no income. In 2011, if Mary and Mark are married, they would be in the 28 -percent tax bracket, and would face a tax liability of $\$ 30,069.50$, the same amount as the married John and Jane. If, however, Mary and Mark were not married, Mark, with no income, would owe no taxes. Mary would still be in the 28-percent tax bracket. But, because the tax brackets for unmarried individuals differ from those that apply to married couples, she would owe $\$ 35,617$ in taxes. ${ }^{70}$ In this case, marriage reduces Mary and Mark's collective tax bill by $\$ 5,547.50$.

\footnotetext{
${ }^{63}$ Rev. Proc. 2011-12 § 1.01, 2011-2 I.R.B. 297 (2010).

${ }^{64} \mathrm{Id}$. Moreover, because the married couple can take a deduction for two personal exemptions, as opposed to the single personal exemption available to an unmarried taxpayer, a married couple pays less in taxes while having a higher gross income than an unmarried individual. I.R.C. § 151 (2006).

${ }^{65}$ Kahng, supra note 31, at 656.

${ }^{66}$ Bittker, supra note 20, at 1429-30.

${ }^{67}$ Rev. Proc. 2011-12 § 1.01, 2011-2 I.R.B. 297 (2010).

${ }^{68} \mathrm{Id}$.

${ }^{69}$ Dorothy A. Brown, Racial Equality in the Twenty-First Century: What's Tax Policy Got to Do With It?, 21 U. ARK. LITTLE Rock L. REV. 759, 760 (1999) ("The marriage bonus is the greatest when only one spouse is contributing to total household income by working in the paid labor market."); see also Kahng, supra note 31 , at 655 .

${ }^{70}$ Rev. Proc. 2011-12 § 1.01, 2011-2 I.R.B. 297 (2010).
} 
In addition to these inequities imposed by the joint filing regime, the different rules applicable to married persons filing jointly increase the complexity of the tax law. For example, "taxpayers filing a joint return use different tax tables, have a different standard deduction, and are entitled to double the maximum exclusion from gain on the sale of a principal residence.",71

As a result of the inequities and complexity that follow joint filing, a number of commentators argue for a return to the individual as the appropriate taxpaying unit. They point out that few developed countries other than the United States still permit married couples to file joint tax returns. ${ }^{72}$ In addition, they observe that "the joint return was enacted not as a result of reasoned tax policy analysis, but rather out of political expediency." ${ }^{73}$ As a result of the lack of policy undergirding the joint return, combined with the trends in the rest of the world, they argue that the United States should replace its joint filing with individual filing for all taxpayers.

Proponents of an individual filing system also argue that marriage does not inherently equate to income-pooling. Although a married couple can act as an economic unit, most states do not require them to do so. ${ }^{74}$ And some scholars argue that a significant percentage of married couples do not pool their income. ${ }^{75}$ To the extent that the tax law permits joint filing to accurately reflect the income of married couples who share their income, evidence that married couples do not share their income argues against the necessity of joint return. That the joint return increases the tax law's complexity and inequity strengthens this argument even more.

In addition, these commentators argue that joint filing hurts women. Under the U.S federal income tax, a taxpayer pays a progressively higher rate of tax on income as her income increases. In 2011 , an unmarried taxpayer pays ten percent of her first $\$ 8,500$ of taxable income, then fifteen percent of her next $\$ 26,000$; ultimately,

\footnotetext{
${ }^{71}$ Samuel A. Donaldson, The Easy Case Against Tax Simplification, 22 VA. TAX REV. 645, 682-83 (2003).

${ }_{72}^{72}$ See, e.g., Kahng, supra note 31, at 652.

${ }^{73} \mathrm{Id}$.

${ }^{74}$ See, e.g., Shari Motro, A New "I Do": Towards a Marriage-Neutral Income Tax, 91 IowA L. REV. 1509, 1519 (2006) ("In the forty-one states that apply common-law principles to marital-property matters, the wage earner is the wage owner during marriage.").

${ }^{75}$ Marjorie E. Kornhauser, Love, Money, and the IRS: Family, Income-Sharing, and the Joint Income Tax Return, 45 HASTINGS L.J. 63, 108 (1993).
} 
she pays thirty-five percent of her income in excess of $\$ 379,150 .^{76}$ Two individual taxpayers each pay taxes on a portion of their income at the lower tax rates. A married couple, however, can only take advantage of the lower rates once. As a result, the secondary earner (traditionally the wife) feels like she pays the same percentage of taxes on her first dollar of income as her husband did on his last dollar of income. ${ }^{77}$ She may decide, in light of her lower after-tax income, that such income is not worth the effort and expense of working and, therefore, stay out of the paid workforce. ${ }^{78}$

Proponents of individual filing also argue that joint filing creates significant inequities between taxpayers. For example, while a married couple may pay higher or lower taxes than an unmarried couple with the same aggregate taxable income, the married couple will always pay less than a single person with the same amount of taxable income. ${ }^{79}$ Moreover, the tax law treats a heterosexual married couple differently than an unmarried couple, even if that unmarried couple pools all of their income and expenses. And this different treatment cannot be justified purely on administrability grounds: even same-sex couples, legally married in a state that permits same-sex marriage, and couples in state-sanctioned civil unions or domestic partnership with the same rights and responsibilities as heterosexual marriage, cannot file a joint return. ${ }^{80}$ Besides the unfairness of treating

\footnotetext{
${ }^{76}$ Rev. Proc. 2011-12 § 1.01, 2011-2 I.R.B. 297 (2010).

77 Anne L. Alstott, Tax Policy and Feminism: Competing Goals and Institutional Choices, 96 CoLUM. L. REV. 2001, 2009 (1996).

78 Amy C. Christian, Joint and Several Liability and the Joint Return: Its Implications for Women, 66 U. CIN. L. REV. 535, 601 (1998) ("Joint return rates, which incorporate both income splitting and aggregation, most likely discourage many married women from entering the work force or from remaining in it when they marry.").

${ }^{79}$ Kahng, supra note 31 , at 660.

${ }^{80}$ Cain, supra note 19, at 805. Recently, however, the I.R.S. Office of Associate Chief Counsel (Procedure and Administration) asserted that unmarried couples in a state-recognized civil union or domestic partnership could, under certain circumstances, file a joint return. Amy S. Elliott, IRS Memo Indicates Civil Unions Are Marriages for Tax Purposes, 133 TAX Notes 794, 794 (2011). In its letter, the I.R.S. says that, for federal income tax purposes, opposite-sex couples "living in a relationship that the state would treat as husband and wife" can file joint tax returns. Letter from Pamela Wilson Fuller, Senior Technician Reviewer, I.R.S. Office of Associate Chief Counsel (Procedure and Administration), to Robert Shair, Senior Tax Advisor, H\&R Block (Aug. 30, 2011), available at http://law.scu.edu/blog/samesextax/file/IRS\%20Civil\%20Union\%20letter.pdf. Still, although it reflects current I.R.S. policy, the letter does not actually provide legal
} 
similarly-situated taxpayers differently, this different treatment imposes real costs on taxpayers. ${ }^{81}$

Given the controversy caused by, and complexity inherent to, the joint return, it is worth inquiring if there is any reason the tax law should take account of marital-or other familial-relationships. Notwithstanding these arguments against the joint return, some scholars argue that the tax law should continue to permit married couples to file joint returns. For example, although not all married couples pool all of their income, the extant studies demonstrate high levels of income-pooling by married couples. ${ }^{82}$ Moreover, some argue, even if joint returns cause some inequities, shifting to individual returns would create administrative and other difficulties that would, ultimately, result in deadweight loss. ${ }^{83}$

Moreover, as Professor Stephanie Hunter McMahon points out, the fact that other countries have switched from joint filing to individual filing provides an example of the costs and benefits of the switch. ${ }^{84}$ She concludes that the change provided both benefits and detriments to women in the United Kingdom. Married women appear to own more investment property than they did before the change. ${ }^{85}$

authority for taxpayers in civil unions or domestic partnerships to file joint returns. See Elliott, supra, at 794 ("David Lee Rice . . . cautioned that the letter holds no weight of authority."). Nonetheless, the letter demonstrates a recognition that joint filing can follow economic unity reflected by institutions other than just traditional marriage.

${ }^{81} I d$. at 806.

${ }^{82}$ See, e.g., Stephanie Hoffer, Adopting the Family Taxable Unit, 76 U. CIN. L. REV. 55,79 n.148 (2007) ("As a result, the argument that family pooling is not supported by empirical data is not well founded, at least as regards basic expenses."); Zelnak, supra note 59, at 351 ("Far from indicating the weakness of the pooling assumption, Kornhauser's data . . . indicates that only $9 \%$ of couples deposit none of their earnings in joint accounts-and even among that $9 \%$, the use of separate accounts does not necessarily negate pooling.").

${ }^{83}$ McMahon, supra note 22, at 755.

${ }^{84}$ Stephanie Hunter McMahon, London Calling: Does the U.K.'s Experience With Individual Taxation Clash With the U.S.'s Expectations?, 55 ST. LoUIS U. L. REV. 159, 161-62 (2010) ("Most of the American scholars who agree with this conclusion do so without examining the many real world examples of [moving to individual filing] that can be found outside America's borders.").

${ }^{85} I d$. at 202-03 ("But while the study found that couples would not shift income to the maximum extent possible to secure a tax reduction, it did find an increase in three outcomes: the proportion of wives having any investment income; the fraction of household investment income owned by wives; and the fraction of households in which the wife held all of the investment income."). 
But there is no clear evidence that the change increased the number of British women who entered into the workforce. ${ }^{86}$ Professor McMahon concludes that eliminating the joint return will benefit some taxpayers while harming others. Ultimately, though, any tax system will create distortions, and these distortions need to be weighed as part of the debate over the future of joint filing. ${ }^{87}$

In addition, marriage plays an important role in American life. It "has enormous value to Americans as an institution that makes social unity possible, even in a world in which individuality has been fully cultivated." 88 Even commentators who do not particularly like the institution of marriage recognize that it is "a dominant and normative institution, with life-altering formal and informal benefits." 89 The Internal Revenue Code reflects this primacy of marriage in the United States, with many special rules aimed at marital or other familial relationships. ${ }^{90}$ Among other things, these special rules may take into account the fact that people act altruistically in certain circumstances, ${ }^{91}$ or they may provide married couples with a "zone of privacy" protected from I.R.S. inquiry. ${ }^{92}$

\section{NON-TRADITIONAL FAMILIES AND THE FUtURE OF THE JOINT RETURN}

\section{A. Non-Traditional Dyadic Taxpayers}

Notwithstanding the controversy surrounding joint filing, few - even those who prefer individual filing — believe that the United States will switch to a mandatory individual filing system, at least in

\footnotetext{
${ }^{86} I d$. at $197-98$.

${ }^{87} I d$. at 218 ("Instead, it requires deciding how to allocate a tax reduction among various family types. Unfortunately, when deciding the best tax unit, there is no choice that simply removes distortions in behavior. Each choice always benefits some family arrangement.").

${ }^{88}$ Maura I. Strassberg, Distinctions of Form or Substance: Monogamy, Polygamy and Same-Sex Marriage, 75 N.C. L. REV. 1501, 1623-24 (1997). In her article, Professor Strassberg argues in favor of recognizing same-sex marriage while, at the same to, argues against decriminalizing, much less legalizing, polygamy. Id. at 1623 . ${ }^{89}$ Davis, supra note 3, at 1962-63.

${ }^{90}$ Theodore P. Seto, The Unintended Tax Advantages of Gay Marriage, 65 WASH \& LEE L. REV. 1529, 1531 (2008). Currently the special tax rules applicable to married person only apply to heterosexual married couples, but there is no reason they should not be expanded to other relationships. See infra notes 94-98 and accompanying text. ${ }^{91}$ Id. at 1538 .

92 Anthony C. Infanti, Decentralizing Family: An Inclusive Proposal for Individual Tax Filing in the United States, 2010 UTAH L. REV. 605, 643 (2010).
} 
the near future. ${ }^{93}$ As a result of the joint return's apparent future, these commentators have focused on making joint filing fairer and more broadly available. ${ }^{94}$ To do so, some argue that same-sex married couples should file (or should be permitted to file) joint returns. ${ }^{95}$ Others would permit anybody in a legally-recognized relationship (e.g., marriage, civil union, domestic partnership) to file a joint return. ${ }^{96}$ Some would expand the availability of joint filing to virtually any couple that demonstrates that they pool their income (while possibly excluding married couples who do not pool their income). ${ }^{97}$ Still others would base joint filing on ownership of income and assets. ${ }^{98}$

None of these proposed expansions, however, requires any fundamental reconsideration of the tax system. If DOMA disappeared today, we know exactly how the current tax regime could incorporate married gay couples, domestic partners, and couples in a civil union: the current marginal rates applicable to a married couple filing jointly would work equally well for any of these couples or, for that matter,

${ }^{93}$ See, e.g., Motro, supra note 74, at 1513 ("However, though mandatory separate filing has many appeals, it is now widely regarded as politically unrealistic."); Lawrence Zelenak, Doing Something About Marriage Penalties: A Guide for the Perplexed, 54 TAX L. REV. 1, 2-3 (2000) ("Although mandatory separate returns for all taxpayers would eliminate all marriage penalties (and bonuses), that does not seem to be a politically possibility in the near future."). Professor Anthony C. Infanti believes that the U.S. shifting to individual filing is "not as politically unrealistic as other commentators believe." Infanti, supra note 92, at 621. Even he, however, sees the change becoming more likely "as time passes," rather than immediately. Id.

${ }^{94}$ See, e.g., McMahon, supra note 22, at 756 ("That conclusion does not mean that the system should not recognize new forms of American families.").

95 See, e.g., McMahon, supra note 22, at 756 ("So, too, should same-sex couples ....”).

${ }^{96}$ See, e.g., Cain, supra note 19, at 851 ("Another possible solution for same-sex couples would be to extend spousal treatment to those couples whose relationships are recognized under state law.").

${ }^{97}$ Motro, supra note 74 , at 1545 . Although this would be the most precise way to determine if a couple should be permitted to file a joint return, it would be administratively unfeasible. Id. Still, the fact that the tax law cannot implement a perfect joint filing regime does not argue against a next-best solution. "Every tax system, of course, trades off accuracy for simplicity to some degree." Kyle D. Logue \& Gustavo G. Vettori, Narrowing the Tax Gap Through Presumptive Taxation, 2 COLUM. J. TAX L. 100, 104 (2011).

${ }^{98}$ Ventry, supra note 27, at 1465 ("Eighty years after Seaborn and sixty years after passage of the income-splitting provision, ownership of income and property remains the guidepost of family taxation"). 
any dyadic relationship. ${ }^{99}$ Actually implementing the change may require a minor legislative or administrative action; references to "husband and wife" 100 would need to become gender-neutral, for example. But such a change need not be burdensome or complicated: already under the Code, "words importing the masculine gender include the feminine as well." ${ }^{\prime 01}$ A similar definitional provision could provide that "husband and wife" referred to any person in a specified relationship.

A tax regime that required individual filing would clearly reduce the inequities between heterosexual married taxpayers and other taxpayers in dyadic relationships who also pool their income. But the fact that the structure of the current tax system could permit other taxpayers in dyadic relationships to file jointly without adding complexity to the tax law suggests that perhaps expanding joint filing can similarly solve the fairness question. And if we assume that mandatory individual filing is currently a political nonstarter, it is worth noting that same-sex marriage does not challenge the tax system as currently constituted.

\section{B. Polygamous Taxpayers}

Tens of thousands of polygamists live in the United States. Experts estimate that between 20,000 and 100,000 fundamentalist

\footnotetext{
${ }^{99}$ There may be enforcement and privacy reasons not to extend joint filing to any two people, or even to any two people who claim to be in a relationship in which they pool their income. Confirming that each couple that claimed economic unity acted as an economic unit would create a nearly insurmountable administrative burden for the I.R.S. Moreover, even if the I.R.S. has the resources to confirm that a couple was, in fact, an economic unit, the inquiry would likely prove overlyintrusive. As such, it makes sense that the tax system would use a proxy, such as state recognition. But the tax law chooses a state-recognized relationship (in this case, opposite-sex marriage) as the proxy for economic unity, there is no reason not to also include other state-recognized relationships with similar legal rights and obligations, including same-sex marriage, domestic partnerships, and civil unions. Any administrative burden the IRS would face in determining whether, in fact, a couple filing jointly had entered into a valid same-sex marriage, civil union, or domestic partnership would be qualitatively the same as the burden in currently faces in determining whether a couple filing jointly is legally married.

${ }^{100}$ See, e.g., I.R.C. § 6013(a) (2006) ("A husband and wife may make a single return jointly of income taxes."). Moreover, the Code defines "joint return" as "a single return made jointly under section 6013 by a husband and wife." I.R.C. $§ 7701$ (a)(38) (2006).

${ }^{101} 1$ U.S.C. $\S 1$ (2006). The Code explicitly incorporates this definitional provision. I.R.C. $\$ 7701(p)(1)(2)(2006 \&$ Supp.).
} 
Mormons 102 living in the Western United States, belong to polygamous households. ${ }^{103}$ In addition to Mormon polygamists, an estimated 50,000 polygamist Muslims live in the United States. ${ }^{104}$ Moreover, several thousand polygamous Hmong live in the United States. $^{105}$

Though their experiences with polygamy undoubtedly differ in many ways, all polygamists share one common experience: by virtue of their polygamy, they violate the law. In 1862, Congress criminalized polygamy in U.S territories. ${ }^{106}$ Ultimately, the Supreme Court determined that anti-polygamy laws did not violate the constitutional right to free exercise of religion. ${ }^{107}$ Today, every state has laws prohibiting polygamy. ${ }^{108}$

${ }^{102}$ Although the Church of Jesus Christ of Latter-day Saints (i.e., the Mormon church) formally discontinued polygamy in 1890 , certain leaders and members believed that polygamy should continue, and formed their own schismatic sects. Janet Bennion, History, Culture, and Variability of Mormon Schismatic Groups, in MOdERN POLYGAMY IN THE United STATES 101, 102 (Cardell K. Jacobson \& Lara Burton, eds., 2011). This Article uses the term "fundamentalist Mormon" to refer to these polygamous groups that trace back to, but broke from, the mainstream Mormon church.

${ }^{103}$ See, e.g., Utah Att'y Gen.'s Office \& Arizona Att'y Gen.'s Office, THE PRIMER: Helping Victims of Domestic Violence and Child ABUSE IN POlygamous COMMUNITIES 12-24 (2006) (estimating more than 27,000 members of various polygamous Mormon groups), available at http://classicweb.archive.org/web/20070719143759/http://attorneygeneral.utah.gov/polygamy/Th e_Primer.pdf; John Gibeaut, Violation or Salvation?: Prosecutors Say It's a Sex Crime. Polygamist Leader Warren Jeffs Says It's Counseling His Flock., 93 A.B.A.J. 26, 26 (2007) (estimating 30,000 polygamists in Western United States and Canada); Jon Krakauer, Under tHE BANNER OF HEAVEN: A STORY OF Violent FAITH 5 (2003) (estimating 30,000 to 100,000 fundamentalist Mormons currently practicing polygamy).

${ }^{104}$ All Things Considered: Some Muslims in U.S. Quietly Engage in Polygamy (NPR radio broadcast May 27, 2008), available at http://www.npr.org/templates/story/story.php?storyId=90857818. In fact, "Philadelphia has the highest density of polygamy, due to a combination of conversions to Islam, currents of racial nationalism, and the demographic effects of male incarceration and underemployment." Davis, supra note 3, at 1974.

${ }^{105}$ Zeitzen, supra note 15 , at 166 .

${ }^{106}$ Morrill Anti-Bigamy Act, 12 Stat. 501 (July 1, 1862).

${ }^{107}$ Reynolds v. United States, 98 U.S. 145, 166 (1889).

${ }^{108}$ Teri Dobbins Baxter, Private Oppression: How Laws That Protect Privacy Can Lead to Oppression, 58 KAN. L. REV. 415, 436 (2010) ("Polygamy is illegal in Texas and every other state."). In spite polygamy's illegality, for political and practical reasons, states often hesitate to enforce their polygamy laws. See Shayna M. Sigman, Evertying Lawyers Know About Polygamy is Wrong, 16 CORNELL J.L. \& PUB. POL'Y 
Although historically Americans have recoiled from polygamy, treating it as a primitive, inferior custom, ${ }^{109}$ recently, polygamy has started to emerge as less alien and more sympathetic. In no small part, HBO's Big Love, a television series chronicling a polygamous family in Utah, and TLC's Sister Wives, a reality television show following a polygamous family in Utah, may lie behind this change in attitude. ${ }^{110}$ By exposing Americans to a (fictional) polygamous family, polygamy arguably loses some of its otherness and danger. ${ }^{111}$ Moreover, in the wake of Texas's mishandled raid of the polygamous Yearning for Zion Ranch, polygamists began to look less like scary despotic usurpers ${ }^{112}$ and more like scared victims of democratically-elected governments. ${ }^{113}$ Moreover, changes in the law may also make polygamy more visible in the future. For example, some polygamists

101, 141-42 (2006) ("The era of under-enforcement began after Short Creek and persists now, over fifty years later.").

${ }^{109}$ See Martha M. Ertman, Race Treason: The Untold Story of America's Ban on Polygamy, 19 COLUM. J. GENDER \& LAW 287, 289 (2010) ("According to this view, polygamy was natural for people of color, but unnatural for White Americans of Northern European descent. When Whites engaged in this unnatural practice, antipolygamists contended, they produced a 'peculiar race."').

${ }^{110}$ Davis, supra note 3, at 1956-57 ("Some have even predicted Big Love might do for polygamists what Will \& Grace and Queer Eye for the Straight Guy did for gays: familiarizing the foreign and smoothing the way for recognition and real rights."); John Schwartz, Polygamist, Under Scrutiny in Utah, Plans Suit to Challenge Law, N.Y. TIMES, Jul. 12, 2011, at A10 (The [polygamous Brown] family is the focus of a reality TV show, "Sister Wives," that first appeared in 2010.").

${ }^{111}$ See, e.g., John Tierney, Who's Afraid of Polygamy, N.Y. Times, Mar. 11, 2006, at A15 ("This story of a husband with three wives in Utah will not terrify Americans. Polygamy doesn't come off as a barbaric threat to the country's moral fabric. It looks more like what it really is: an arrangement that can make sense for some people in some circumstances, but not one that could ever be a dangerous trend in America.").

${ }^{112}$ See, e.g., Maura Strassberg, The Crime of Polygamy, 12 TEMP. Pol. \& CIV. RTS. L. REV. 353, 356 (2003) ("In particular, I argued that polygyny not only fails to produce critical building blocks of liberal democracy, . . . but promotes a despotic state populated by subjects rather than citizens.").

${ }^{113}$ On April 3, 2008, Texas law enforcement raided the Yearning for Zion Ranch, a polygamous community, and removed more than 400 children from their families. Tamara N. Lewis Arredondo, Toward a Viable Policing Model for Closed Religious Communities, 35 AM. J. CRIM. L. 107, 110-11 (2008). A year later, with no evidence of danger to the children, all except for one had been returned to their families. Linda F. Smith, Child Protection Law and the FLDS Raid in Texas, in MODERN POLYGAMY IN THE United STATES 301, 317 (Cardell K. Jacobson \& Lara Burton, eds., 2011) 
use the Supreme Court's decision in Lawrence v. Texas, ${ }^{114}$ which held unconstitutional a Texas anti-sodomy law, to argue that criminalizing polygamy also violates the Constitution. ${ }^{115}$

Although polygamy, like same-sex marriage, domestic partnerships, and civil unions, represents an alternative to the traditional American family, it presents unique challenges in designing a tax regime. ${ }^{116}$ Unlike dyadic same-sex marriage, polygamy presents a significant challenge to a tax filing system designed to treat married persons as an economic unit, where it assumes that economic unit consists of two people. For example, legalized polygamy would challenge the design of the marginal tax brackets. The tax law includes four sets of marginal tax brackets, applying respectively to married persons filing jointly and surviving spouses, heads of household, unmarried individuals, and married persons filing separately. ${ }^{117}$ Treasury adjusts the size of the brackets annually for inflation. ${ }^{118}$ Currently, the tax brackets for married persons filing jointly range from twice the size of the brackets for unmarried individuals at the lower income levels to identical at the highest income levels. ${ }^{119}$

The current marginal tax brackets do not provide any assistance in determining the appropriate marginal tax brackets that would apply to polygamous families. In a world of legalized polygamy that treated spouses as an appropriate taxable unit, polygamous taxpayers would still encounter potentially significant marriage

\footnotetext{
114539 U.S. 558 (2003).

${ }^{115}$ See Complaint for Declaratory, Injunctive, and Other Relief at 7-8, Brown v. Herbert, No. 2:11-CV-00652 (D.C. Utah Jul. 13, 2011).

${ }^{116}$ Cf. Elizabeth M. Glazer, Sodomy and Polygamy, 111 ColuM. L. ReV. Sidebar 66, 78

http://www.columbialawreview.org/assets/sidebar/volume/111/66_Glazer.pdf

(2011),

("Polygamy is different from dyadic marriage, and it is different from homosexuality.").

${ }^{117}$ I.R.C. § 1(a)-(d) (2006).

${ }^{118} I d . \S 1$ (f).

${ }^{119}$ In 2011, the 10 percent and 15 percent tax brackets were twice as large as that for unmarried individuals in the same respective tax brackets. The ceiling for the 25 percent tax bracket for married individuals filing jointly terminated at about twothirds more income than the same bracket for married individuals, while the 28 percent bracket ended about 20 percent higher for married couples filing jointly than for single individuals. The 33 percent bracket, on the other hand, ended at the same income level for married persons filing jointly and for single individuals, while the 35 percent bracket had no upper limit. Rev. Proc. 2011-12, 2011-2 I.R.B. 297.
} 
penalties in comparison to both four unmarried taxpayers and two dyadic couples. ${ }^{120}$

For example, the polygynous Henrickson family consists of Bill and his three wives, Barbara, Nicki, and Margene. ${ }^{121}$ In 2011, each earns $\$ 25,000$. If the tax law permitted polygamous spouses to file jointly, but required them to use the current marginal tax brackets, the Henricksons would quickly face a significant marriage penalty. Their collective income would put them in the 25-percent tax bracket, and would owe taxes of $\$ 17,250$. $^{122}$ By contrast, four unmarried individuals with $\$ 25,000$ of taxable income would each be in the 15percent tax bracket and would each pay taxes of $\$ 3,325$. Collectively, the four would pay a total of $\$ 13,300$, almost $\$ 4,000$ less than the Henricksons. ${ }^{123}$ Two dyadic couples, each with $\$ 50,000$ in taxable income would also be in the 15-percent tax bracket, and would also collectively pay $\$ 13,300 .{ }^{124}$

In addition to the marriage penalty applicable to polygamous taxpayers, applying the current brackets would accentuate the disincentive for the secondary (and, in the case of polygamous families, tertiary, etc.) earner to work. For a dyadic married couple, the secondary earner's income is stacked on top of the primary earner's. ${ }^{125}$ In a polygamous marriage, using current marginal tax brackets, the secondary earner's income would be stacked on top of the primary earner's, and then the tertiary earner's income would be stacked on top of both the primary and the secondary earner's. Each subsequent earner would potentially pay taxes on her first dollar of income at the highest marginal rate of the prior earner. Because each subsequent worker would enjoy progressively less after-tax income, work would become even less appealing for each additional plural spouse, even though polygamous families may need additional plural spouses' incomes to make ends meet. ${ }^{126}$

\footnotetext{
${ }^{120}$ See infra Section V.B.

${ }^{121}$ The Henricksons were the main characters of HBS's Big Love. See Alessandra Stanley, One Man, Three Wives and Many Troubles, N.Y. Times, Mar. 10, 2006, at E21.

${ }^{122}$ Rev. Proc. 2011-12, 2011-2 I.R.B. 297.

${ }^{123} \mathrm{Id}$.

${ }^{124} \mathrm{Id}$.

${ }^{125}$ See supra notes 76-78 and accompanying text.

126 See IRWIN ALTMAN \& JOSEPH GINAT, POLYGAMOUS FAMILIES IN CONTEMPORARY SOCIETY 84 (1996 ("Most contemporary plural families struggle
} 
To ameliorate these heightened marriage penalty and secondary earner problems, Congress could create alternative brackets, applicable to polygamous taxpayers. But creating such individualized tax brackets would create administrative burdens as Congress and the Treasury Department tried to determine how to design those brackets. ${ }^{127}$

If the tax law did not recognize polygamous marriage, either requiring all parties to the marriage to file as individuals filing separately or permitting two to file as spouses and the others to file as individuals, polygamous families would face disadvantages as compared with dyadic married couples. ${ }^{128}$ In spite of polygamous spouses' potentially pooling their assets-either informally or as a result of community property laws-the tax law would treat such polygamous taxpayers as economically independent. In cases where only one spouse worked, polygamous families forced to file as unmarried individuals would pay the same amount as unmarried individuals, and more than dyadic married couples with similar income. In many cases, polygamous families' income lags behind that of the surrounding communities. ${ }^{129}$ This higher tax bill could potentially prejudice low- but single-income polygamous families.

\section{TAX DISCRIMINATION AND FAIRNESS}

Once a state legalizes polygamy, the federal government will need to determine how to deal with polygamous taxpayers. Currently, DOMA prevents the federal government from recognizing polygamous marriage, ${ }^{130}$ but DOMA's long-term future appears shaky. ${ }^{131}$ Moreover, as a normative matter, if polygamy becomes legal

financially and are hard put to make ends meet. . . In most cases, some wivesoften many wives-and all husbands worked to earn money.").

${ }^{127}$ See infra Section V.E.

${ }^{128}$ See infra Section V.A.

${ }^{129}$ See, e.g., Tim B. Heaton \& Cardell K. Jacobson, Demographic, Social, and Economic Characteristics of a Polygamist Community, in MODERN POLYGAMY IN THE UNITED STATES: HistoriCAL, CULTURAL, AND LEGAL IsSUES 151, 158 (Cardell K. Jacobson \& Lara Burton, eds., 2011) ("[O]verall income is comparatively low in the [Hildale-Colorado City] polygamous community. The median family income is 37 percent lower than in Utah.”).

1301 U.S.C. $§ 7$ (2006) (“'TT]he word 'marriage' means only a legal union between one man and one woman as husband and wife ....").

${ }^{131}$ See Gill v. Office of Pers. Mgmt., 699 F. Supp. $2 d$ 374, 393 (D. Mass. 2010); see also Leon Gabinet, Refusal to Grant Same-Sex Divorce: Uncertainty in Tax, Property, and Marital Status Issues, 29 J. TAX’N InVESTMENTS 67, 71 (2011) (“It is 
in one or more states, Congress should not attempt to use the tax law to show its disapproval of polygamy. Already the tax law's refusal to recognize same-sex marriage has led to harms, both to gay taxpayers and to the tax system, and its systematic refusal to recognize polygamous marriage would result in similar harms. The principal purpose of the tax law is to raise revenue for the government in a fair manner. ${ }^{132}$

Notwithstanding these fundamental principles of fairness and revenue, Congress has used the tax law to prevent and to punish undesirable activities. For example, the tax law can explicitly prevent taxpayers from reducing their income in certain ways; ${ }^{133}$ alternatively, it can create an unfavorable result in the hopes of discouraging revenue-reducing actions. ${ }^{134}$ In addition, the tax law can penalize those who decided to engage in disfavored acts. It penalizes taxpayers who underreport their income, ${ }^{135}$ who fail to file returns, ${ }^{136}$ and even those who bounce their checks when they pay their taxes. ${ }^{137}$ Taxpayers who engage in tax shelter transactions intended to illegally evade taxes face

quite possible that the constitutionality of DOMA may soon be at issue in the [U.S. Supreme] Court given that at least one federal district judge has already held it to be unconstitutional in two separate cases ....").

${ }^{132}$ Richard M. Bird \& Eric M. Zolt, The Limited Role of the Personal Income Tax in Developing Countries, 16 J. ASIAN ECON. 928, 929 (2005) ("[T]he main reason for a tax system is to allocate the cost of government in some fair way.").

${ }^{133}$ For example, if a taxpayer acquires control of a corporation for the principal purpose of evading tax through a deduction, credit, or other allowance, the I.R.S. can disregard a taxpayer's putative deduction, credit, or other allowance. I.R.C. § 269(a) (2006).

${ }^{134}$ For example, some taxpayers would defer-possibly indefinitely—their payment of taxes by investing through a tax haven corporation. See Craig M. Boise, Breaking Open Offshore Piggybanks: Deferral and the Utility of Amnesty, 14 GEO. MASON L. REV. 667, 683 (2007). Rather than prohibiting taxpayers' use of tax havens, the Kennedy administration enacted the subpart $F$ rules, which taxed certain persons trying take advantage of tax havens on the income earned by the tax haven corporation, even if they did not currently receive that money. Id. at 684. Although U.S. taxpayers could still invest through tax havens, these rules made such investment less attractive.

${ }_{135}^{13}$ I.R.C. $\$ 6662$ (a) (2006).

${ }^{136}$ I.R.C. § 6651(a)(1) (2006).

${ }^{137}$ I.R.C. $§ 6657$ (2006). 
must disclose their participation and, if they fail to disclose, face stiff penalties. $^{138}$

Most of the undesirable activities that the tax law prevents or discourages relate to the tax law's revenue-raising provisions. But in certain cases, Congress has used the tax law to discourage behaviors not related to tax. The tax law may be uniquely situated to address certain non-revenue-related harms; for example, the tax law can discourage certain activities that create negative externalities by forcing a taxpayer to internalize the costs of those activities. ${ }^{139}$

In general, the tax law should not penalize a taxpayer's family structure, especially where that family structure does not cause tax evasion or produce other negative externalities that the taxpayer should internalize. In general, the tax law should minimize the ways in which it treats people differently. ${ }^{140}$ Using the tax law to disapprove of certain types of marriage-including same-sex marriage and polygamy-serves no revenue-related purposes. ${ }^{141}$ Because a taxpayer's marriage does not implicate tax evasion, it does not discourage tax-evasive behavior. Moreover, alternative family structures do not create externalities. ${ }^{142}$

${ }^{138}$ I.R.C. § 6707A(a) (2006); see Samuel D. Brunson, Repatriating Tax-Exempt Income: Tax Havens, Blocker Corporations, and Unrelated Debt-Financed Income, 106 Nw. U. L. REV. (forthcoming 2012).

${ }^{139}$ Victor Thuronyi, The Concept of Income, 46 TAX L. REV. 45, 93 (1990).

${ }^{140}$ Edward J. McCaffery, Slouching Towards Equality: Gender Discrimination, Market Efficiency, and Social Change, 103 Yale L.J. 595, 645 (1993) ("[A] progressive tax system affects different people differently, although we try to minimize the differing effects through formal concepts such as horizontal equity, with its mandate to treat like cases alike.").

${ }^{141}$ Tax laws have, in fact, been used to discourage and/or penalize polygamous relationships. Colonial African governments imposed head taxes, under which men had to pay a set amount for each wife. Miriam Koktvedgaard Zeitzen, supra note 15, at 146. A highly regressive form of tax, Lawrence Zelenak, The Puzzling Case of the Revenue-Maximizing Lottery, 79 N.C. L. REV. 1, 21 (2000), the colonial governments intended for this type of tax to constitute such an economic burden that eventually polygyny would disappear. Zeitan, supra note 15, at 146 . In fact, it merely converted de jure polygamy into de facto polygyny, in some places increasing the prevalence of polygamy. Id.

${ }^{142}$ See, e.g., Laura Langbein \& Mark A. Yost, Jr., Same-Sex Marriage and Negative Externalities, 90 SoC. SCI. Q. 292, 305-06 (2009) ("The results above show that laws permitting same-sex marriage or civil unions have no adverse effect on marriage, divorce, and abortion rates, the percent of children born out of wedlock, or the percent of households with children under 18 headed by women.”). 
Penalizing these alternative family structures using the income tax is, therefore, unfair. And unfairness creates real harm, both to the taxpayers and to the tax system. The harms to taxpayers include the psychic harms of feeling excluded, devalued, or even discriminated against by the larger society, ${ }^{143}$ in addition to the expense and administrative costs of paying taxes. ${ }^{144}$ In addition, an unfair tax system may cause taxpayers to lose faith in the tax law. ${ }^{145}$

\section{A. DOMA and Same-Sex Marriage}

Congress has departed from the principles of fairness and nondiscriminatory taxation in its treatment of married same-sex couples. In spite of the lack of negative externalities and revenue loss associated with same-sex marriage, Congress has refused to recognize it for tax purposes. But Congress's refusal to recognize same-sex couples as married for tax purposes has proven unfair and problematic, and illustrates some of the problems with using the tax law to discourage behavior states affirmatively permit.

In 2004, after the Supreme Judicial Court of Massachusetts determined that prohibitions on same-sex marriage violated the Massachusetts constitution, ${ }^{146}$ Massachusetts became the first state to

${ }^{143}$ Professor Anthony Infanti explains that, to him, as a gay man,

My own view of the Code and its treatment of same-sex couples is necessarily colored by my experience of life as a gay man. The sum of this experience, which constitutes a narrative in its own right, casts a far less favorable light on the Code. For me, the Code is not neutral; rather, it appears to be just another manifestation of the fluid mixture of hostility, bewilderment, and discomfort that generally characterize society's reaction to homosexuality. From my perspective, I can't help but see the Code as another weapon for discrimination and oppression in society's already well-stocked arsenal.

Anthony C. Infanti, The Internal Revenue Code as Sodomy Statute, 44 SANTA Clara L. ReV. 763, 767-68 (2004). See also John V. Orth, Night Thoughts: Reflections on the Debate Concerning Same-Sex Marriage, 3 NEV. L.J. 560, 565 (2003) ("[C]ouples who cannot be legally married may feel that their relationship is devalued by society.").

144 "Even tax preparation can cost more, since gay couples have to file two sets of returns." Tara Siegel Bernard \& Ron Lieber, The High Price of Being a Gay Couple, N.Y. TIMES, Oct. 2, 2009, at A1.

${ }^{145}$ See, e.g., Nancy J. Knauer, Heteronormativity and Federal Tax Policy, 101 W. VA. L. REV. 129, 218 (1998).

${ }^{146}$ Goodridge v. Dep't of Pub. Health, 440 Mass. 309, 312 (Mass. 2003) ("The question before us is whether, consistent with the Massachusetts Constitution, the 
legalize same-sex marriage. ${ }^{147}$ Other states followed and today five states and the District of Columbia permit same-sex couples to marry. ${ }^{148}$ In spite of this, the federal tax law does not recognize such couples as married. ${ }^{149}$

The tax law's refusal to recognize same-sex marriage does not rest on any tax policy consideration. Instead, its failure to treat samesex married couples in the same manner as it treats heterosexual married couples results solely from the application of DOMA, a law intended to limit the viability of same-sex marriages and, at the same time, to signal Congress's disapproval of such marriages. ${ }^{150}$ Various commentators have decried the application of DOMA to tax law, objecting to the inequity between opposite-sex and same-sex couples.

For example, the tax law's refusal to recognize statesanctioned same-sex marriage creates unnecessary uncertainty for gay taxpayers. Because the tax law refuses to acknowledge their marriage, same-sex married couples must "settle on an appropriate tax classification for transactions that occur within the couple." ${ }^{151}$ But the proper application of the tax law to same-sex married couples is, at best, uncertain. ${ }^{152}$ As they navigate the uncertainty, however, gay couples must nonetheless classify their transactions correctly. If they

Commonwealth may deny the protections, benefits, and obligations conferred by civil marriage to two individuals of the same sex who wish to marry. We conclude that it may not.").

${ }^{147}$ Pam Belluck, Massachusetts Arrives at Moment for Same-Sex Marriage, N.Y. TIMES, May 17, 2004, at A16 ("Against a backdrop of whoops and cheers and a party that spilled onto the streets, gay and lesbian couples here began filling out applications for marriage licenses at 12:01 a.m. on Monday, when Massachusetts became the first state in the country to allow them to marry.").

${ }^{148}$ David D. Meyer, Fragmentation and Consolidation in the Law of Marriage and Same-Sex Relationships, 58 AM. J. CoMP. L. 115, 126 (2010).

${ }^{149}$ See supra note 13 and accompanying text.

${ }^{150}$ DOMA substantively both defined marriage as consisting solely of a man and a woman for federal purposes and authorized states to refuse to recognize same-sex marriages performed in other states. See, e.g., Susan R. Klein, Independent-Norm Federalism in Criminal Law, 90 CALIF. L. REV. 1541, 1561 (2002). In their public statements, however, members of Congress expressed animus toward same-sex marriage. See, e.g., Gill v. Office of Pers. Mgmt., 699 F. Supp. 2d 374, 378 (D. Mass. 2010).

${ }^{151}$ See Infanti, supra note 143, at 783.

${ }^{152}$ See, e.g., Anthony C. Infanti, Tax [O>Equity<O], 55 Buffalo L. REV. 1191, 1238 (2008). 
get it wrong, same-sex married couples could face significant civil and criminal penalties. ${ }^{153}$

Not treating married same-sex taxpayers as spouses for tax purposes also violates the norm of horizontal equity. Horizontal equity demands that similarly-situated taxpayers pay similar amounts of tax. ${ }^{154}$ While horizontal equity is not the sole criterion of a fair tax system, its presence remains a constant across several formulations of a just tax system. ${ }^{155}$ Notwithstanding the place of horizontal equity in a just tax system, however, a same-sex married couple faces a different tax bill than an opposite-sex married couple with precisely the same income, deductions, and credits. ${ }^{156}$ As a result, the tax law's refusal to recognize same-sex marriage, with its violation of horizontal equity, results in an unfair tax system.

In addition to the various examples of unfairness to gay taxpayers caused by the tax law's refusal to recognize same-sex marriage, this refusal can potentially lead to bad tax results. The tax law generally assumes that taxpayers will act selfishly, and uses that selfishness in part to police bad behavior by taxpayers. ${ }^{157}$ In most arm's-length transactions, both parties attempt to negotiate the best

153 Id.

${ }^{154}$ See supra note 61.

${ }^{155} I d$. at 114-16 ("[T]he requirement of [horizontal equity] remains essentially unchanged under the various formulations of distributive justice, ranging from Lockean entitlement over utilitarianism and fairness solutions."); see also Brian Galle, Tax Fairness, 65 WASH. \& LEE L. REV. 1323, 1328 (2008) ("I argue that [horizontal equity] can be justified both by the unique purpose of the revenue function as well as on welfare grounds."). While an important goal of the tax law, however, the tax law does not require similarly-situated taxpayers to be treated similarly in all situations. See, e.g., Hostar Marine Transp. Sys. v. United States, 592 F.3d 202, 210 (1st Cir. 2010) ("Despite the goal of consistency in treatment, the IRS is not prohibited from treating such taxpayers disparately. Rather than being a strict, definitive requirement, the principle of achieving parity in taxing similarly situated taxpayers is merely aspirational.").

${ }^{156}$ See, e.g., Christopher T. Nixon, Should Congress Revise the Tax Code to Extend the Same Tax Benefits to Same-Sex Couples as are Currently Granted to Married Couples?: An Analysis in Light of Horizontal Equity, 23 S. ILL. U. L. J. 41, 44 (1998) ("As a result, the current Code continues to give preferential treatment to married couples as compared to same- sex couples by granting married couples tax benefits not granted to same-sex couples. Because of this preferential treatment, the current Code lacks horizontal equity and, thus, is violative of both tax and social policy.").

${ }^{157}$ See, e.g., Seto, supra note 90, at 1538 ("The Code's general rules are written on the assumption that taxpayers are self-interested, unaffiliated individuals-the atomistic rationalists of the classic economic model."). 
deal for themselves. Usually, though, the best result for one party differs from and, to some extent, conflicts with, the best result for the other. ${ }^{158}$ As such, the parties' ultimate agreement requires some compromise and, rather than resulting in collusion that permits the parties to evade taxes, approximates the true value of their deal. In certain relationships, including familial relationships, the tax law relaxes this assumption of selfishness, and, as such, may ignore transactions that lack economic reality. ${ }^{159}$ Because the tax law does not recognize same-sex couples' marriages as marriage for tax purposes, however, the tax law assumes that gay taxpayers will act selfishly. Where, instead, they act altruistically, they can structure transactions in an abusive manner to take advantage of the tax law's assumption of selfishness. ${ }^{160}$

Finally, the federal government's refusal to recognize same-sex marriages recognized under state law arguably violates the Constitution. The current constitutional regime leaves to the states the right to define marriage. ${ }^{161}$ Commentators have argued that the federal government's refusal to recognize valid same-sex marriages "unconstitutionally usurps state control of domestic relations." 162 Defenders of DOMA argue that it does not limit state definitions of marriage; it only serves to create a single federal definition of marriage. ${ }^{163}$ But at least one court has found that, even with this putative purpose, DOMA violates the Constitution. ${ }^{164}$

\footnotetext{
${ }^{158}$ A sale represents the simplest example of this conflict. The seller wants to receive the highest price possible for her asset in order to maximize her gain. The buyer, on the other hand, wants to pay as little as possible. Because their positions are adversarial and in conflict, the price on which they eventually settle should approximate an objective value for the asset.

${ }^{159}$ I.R.C. § 7701(o).

${ }^{160}$ See. e.g., Seto, supra note 90, at 1544 ("But if my thesis is correct-one of the principal purposes of the related party rules is to prevent tax-abusive transactions whenever the assumption of selfishness fails - then we should all be troubled by the tax-abusive consequences of not including gay marriage as a listed relationship automatically invoking those rules.").

${ }^{161}$ See, e.g., Evan Wolfson \& Michael F. Melcher, Constitutional and Legal Defects in the "Defense of Marriage" Act, 16 QuINNIPIAC L. REV. 221, 231 ("The Tenth Amendment, federalism, the absence of enumerated congressional power, and history all make clear that states, not the federal government, define and regulate civil marriage, subject only to U.S. constitutional constraints.").

${ }^{162} I d$. at 233 .

${ }^{163}$ Gill v. Office of Pers. Mgmt., 699 F. Supp. 2d 374, 391 (D. Mass. 2010).

${ }^{164} I d$. at 393.
} 


\section{B. Polygamists and Tax Evasion}

The arguments in favor of the tax law's recognizing same-sex marriage would also argue for the tax law's recognition of legalized polygamous marriage as marriage. Without such recognition, polygamists would face uncertainty, the tax law would violate horizontal equity, other bad tax results could follow, and the tax law's response could arguably violate the Constitution.

Still, the possibility exists that polygamists differ fundamentally from other taxpayers in such a way that they deserve to be treated differently. ${ }^{165}$ One way in which polygamous differs significantly from same-sex marriage in relation to tax: nobody accuses same-sex couples of systemically evading taxes. ${ }^{166}$ Critics of polygamy, on the other hand, cite tax evasion as one of the litany of evils perpetrated by polygamists. ${ }^{167}$ If polygamists approach taxes in a way fundamentally different from other Americans, that would provide some justification for treating polygamous taxpayers differently, perhaps trumping the general fairness considerations.

Do polygamists evade taxes more than other Americans? No study has explored polygamists' tax compliance. Without such empirical evidence of how polygamists compare with non-polygamists in their payment of taxes, we cannot answer the question definitively. We can, however, look at the specific accusations of tax evasion leveled against polygamists and evaluate such accusations' connection to polygamy.

In general, individual U.S. taxpayers pay the taxes they owe. The I.R.S. estimates that, in 2001, it collected over 86 percent of the

165 For example, Professor Strassberg claims that the "social and political implications" of same-sex marriage differ significantly from those of polygamous marriage. The former she finds fundamentally democratic, while the latter she finds inherently despotic. Strassberg, supra note 88, at 1615.

${ }^{166}$ This notwithstanding Professor Theodore Seto's documentation of tax advantages that committed same-sex couples can enjoy as long as the tax law does not recognize their relationship, see generally Seto, supra note 90, and notwithstanding Professor Anthony Infanti's call for civil disobedience by gay taxpayers. See generally Anthony C. Incanti, Homo Sacer, Homosexual: Some Thoughts on Waging Tax Guerrilla Warfare, 2 UnBOUND: HARVARD J. LEGAL LEFT 27, 53 (2006) ("To be clear, when I speak here of an 'open' challenge, I contemplate the filing of returns that on their face challenge the current application of the tax laws to same-sex couples.").

${ }^{167}$ See supra note 3 and accompanying text. 
taxes that should have been paid. ${ }^{168}$ But this high level of compliance is not evenly distributed; instead, compliance rates vary widely, depending on the type of income a taxpayer earns. Taxpayers declare and pay taxes on about 99 percent of their wages and other income subject to significant information reporting and withholding requirements. ${ }^{169}$ On the other hand, taxpayers only declare and pay taxes on about half of their business income, which often consists of cash not subject to reporting or withholding rules. ${ }^{170}$ And I.R.S. statistics indicate that taxpayers only reported and paid taxes on 28 percent of their farm income. ${ }^{171}$

Although critics of polygamy do not have data on whether and how polygamists evade taxes, they do provide anecdotal examples. For example, on July 24, 2008, the Senate Judiciary Committee held a hearing entitled, "Crimes Associated with Polygamy: The Need for a Coordinated State and Federal Response."172 In his introduction to the hearing, Senator Harry Reid explained that witnesses at the hearing would "describe a web of criminal conduct that includes welfare fraud, tax evasion, massive corruption and strong-arm tactics to maintain the status quo." 173 In the hearings, witnesses alleged that the Fundamentalist Church of Jesus Christ of Jesus Christ of Latter-Day Saints ("FLDS"), one of the largest Mormon polygamous communities, believed in "starving the beast," meaning "F.L.D.S. members should avoid paying taxes at all costs and should also apply for every possible

\footnotetext{
${ }^{168}$ I.R.S. and U.S. Dep't of the Treasury, Reducing the Tax Gap: A Report on Improving Voluntary Compliance 1 (2007) [hereinafter Reducing the Tax Gap], available at http://www.irs.gov/pub/irsnews/tax_gap_report_final_080207_linked.pdf. The I.R.S. calculated this compliance rate after factoring in late payments and I.R.S. enforcement actions. Id. ${ }^{169}$ Id. at 14.

${ }^{170}$ Susan Cleary Morse, Stewart Karlinsky, \& Joseph Bankman, Closing the Tax Gap: Cash Businesses and Tax Evasion, 20 StAN. L. \& POL'Y REV 37, 39 (2009).

${ }^{171}$ Reducing the Tax Gap, supra note 168, at 14.

${ }^{172}$ Hearing, Senate Judiciary Committee, Crimes Associated with Polygamy: The Need for a Coordinated State and Federal Response (July 24, 2008), [hereinafter Crimes Associated with Polygamy] available at http://judiciary.senate.gov/hearings/hearing.cfm?id=e655f9e2809e5476862f735da13 $\underset{173}{\operatorname{ed} 24 c .}$

173 Testimony of Harry Reid, available at http://judiciary.senate.gov/hearings/testimony.cfm?id=e655f9e2809e5476862f735da 13ed24c\&wit_id=e655f9e2809e5476862f735da13ed24c-1-1.
} 
type of government assistance that is available, whether they are eligible or not." 174

Polygamists allegedly avoid paying taxes in two ways: they claim credits and deductions to which they are not entitled and they fail to report some or all of the income they earn. For example, in the Senate Judiciary Committee hearing, one witness testified that "[i]t was standard procedure for 'spiritual wives' [i.e., plural wives not legally married to their husband] to list themselves as the 'head of household' on their income tax returns for the benefit of the tax credit." 175 This accusation is problematic, however, for one major reason: these plural wives probably qualify to file as head of households. Filing as a "head of household" entitles a tax filer to "take advantage of special tax rates." ${ }^{176}$ A taxpayer qualifies for these special tax rates if, at the end of the year, she is unmarried, her dependent child (or children) live with her for at least half the year, and she provides at least half of the cost of maintaining her household. ${ }^{177}$ Because neither the states nor federal law recognizes polygamous marriage, most polygamous spouses are not married for tax purposes; provided that a polygamous wife's children live with her and she provides half of their support, she in fact qualifies as the head of household and, by filing using that status, follows the tax law and does not evade her taxes.

Critics of polygamy also claim that polygamists "avoid income taxes by paying each other wages under the table." ${ }^{, 78}$ But, in light of the I.R.S.'s compliance statistics, the evasion problem appears to result less from the taxpayers' status as polygamists and more from their work in less-formal industries. And, at least among some groups of Mormon polygamists, men are more likely to work in agricultural

\footnotetext{
174 Testimony of Carolyn Jessop, available at http://judiciary.senate.gov/hearings/testimony.cfm?id=e655f9e2809e5476862f735da 13ed24c\&wit_id=e655f9e2809e5476862f735da13ed24c-3-3; but see Testimony of Dan Fischer ("While you'll probably gather important information related to tax fraud and welfare fraud, there are probably some who pay their taxes fairly and for sure there are some who are eligible for welfare and should be the recipients of its benefits."), available at http://judiciary.senate.gov/pdf/08-0724Daniel_Fischer_Testimony.pdf.

175 Id.

${ }^{176}$ Adam Chase, Tax Planning for Same-Sex Couples, 72 DENV. U.L. REV. 359, 385 (1995).

${ }^{177}$ I.R.C. $\$ 2(b)(1)(2006)$.

${ }^{178}$ Griggs, supra note 3, at A1.
} 
and construction jobs than the surrounding population. ${ }^{179}$ Taxpayers in these fields tend to underreport their income in general. Critics of polygamy have not provided any evidence that polygamists are so different than other Americans that, if they worked in jobs subject to wage withholding and reporting, they would continue to evade taxes. Transitioning polygamists to a more-formal job market would thus likely provide a better solution to their tax evasion than would refusing to recognize their marriages for tax purposes. ${ }^{180}$

Should polygamy become legal, then, Congress's failure to treat same-sex marriages equitably under the tax law does not justify its refusal to acknowledge and deal with polygamy for tax purposes. Refusing to provide rules for polygamous families would create the same inequities, uncertainties, and opportunities for abuse that refusing to acknowledge the marriages of same-sex couples does. At the same time, it would do nothing to prevent polygamists' alleged tax-evasive behavior.

\section{FILING SOLUTIONS}

The current absence of legal polygamy in the United States poses a significant impediment to designing a tax regime that can handle polygamous taxpayers. Although supporters call polygamy the "next civil rights battle," 181 no state has made any serious move toward recognizing, legalizing, or even decriminalizing it. Nobody knows the legal framework that would underlie legalized polygamy. Given the differences between the various groups that practice polygamy, we cannot currently know how polygamous families would function, legally or economically.

\footnotetext{
${ }^{179}$ Heaton \& Jacobson, supra note 129 , at 157.

180 Legalizing-or even just decriminalizing-polygamy could help transition polygamists into the formal economy. Currently, polygamy is against the law in many states. And polygamists may justifiably believe that, if the state notices them, it will prosecute them. For example, "David O. Leavitt, the Juab County prosecutor ...., said he had not heard of Tom Green [a polygamist] until he saw him several years ago on a television talk show, discussing his life. To Mr. Leavitt, . . . it was an admission of guilt worth pursuing." Michael Janofsky, Trial Opens in Rare Case of a Utahan Charged With Polygamy, N.Y. TiMES, May 15, 2001, at A12. And, more recently, shortly after a reality television show featuring polygamist Kody Brown and his family began to air, Utah law enforcement officials announced "that the family was under investigation for violating the state law prohibiting polygamy." John Schwartz, Polygamist, Under Scrutiny in Utah, Plans Suit to Challenge Law, N.Y, TIMES, Jul. 12, 2011, at A10.

${ }^{181}$ Davis, supra note 3, at 1957.
} 
Still, even without a clear idea of how legalized polygamy would look or when it would arrive, two important considerations justify asking the second-generation question of how the tax law could accommodate polygamous taxpayers for at least two reasons. First, as a practical matter, when and if polygamy becomes legal, polygamous families will immediately need to file tax returns and pay taxes. Although Congress could determine how such families should file and pay their taxes after a state legalized polygamy, it would have a limited amount of time to do so. Moreover, if the discussion of tax and other rules governing the interaction of polygamous families and the outside culture occur at the same time as the discussion of rules governing such families' internal dynamics, the rules can be better tailored to polygamists' unique experiences and needs.

Second, even if polygamy never becomes legal, considering how the tax law would treat polygamous families provides a new and different perspective on tax policy. All policy discussions about joint filing for married couples have assumed a baseline of dyadic couples. Whether the couple in question was of the same or opposite gender, in a legally-sanctioned relationship or not, whether they shared their income and assets or not, the stakes did not change. But adding a one or more partners to the taxable unit raises the stakes, potentially increasing both the benefits and burdens of the joint filing system. Even without polygamy, such new perspective may help to crystallize the benefits and burdens of joint filing.

In order to propose a series of potential tax regimes, and to analyze their pros and cons, this Article must make certain assumptions. First, the potential solutions proposed in this Article assume that at least one state legalizes and regulates polygamous marriage. ${ }^{182}$ Second, the proposed solutions assume a certain type of

\footnotetext{
${ }^{182}$ If polygamous spouses act in economic unity, the legality of their relationship may be theoretically irrelevant. But, like unregulated dyadic relationships, treating polygamists whose marriages are not recognized by a state as married for tax purposes could present both political and administrative problems. Without some sort of officially-sanctioned and -recorded relationship, the process of determining the economic reality of a polygamous family would require significant I.R.S. resources, and would likely also require intrusive verification of the facts of the polygamous relationship. Ultimately, it may be preferable to recognize chosen families, or to otherwise take into account a broader definition of family in dealing with the tax law. But the question of whether the tax law should recognize a nonstate-sanctioned family is beyond the scope of this Article; instead, it will be the topic of a future project.
} 
polygamous relationship. Although providing an individualized tax system tailored to each family would perhaps create the fairest system, doing so would add unnecessary complexity to the tax law and would be virtually unadministrable. People who enter into polygamous marriages do so with different motivations and polygamous families differ in interpersonal and economic configurations. ${ }^{183}$

Thus, the proposed regimes assume that a polygamous marriage is structured in a hub-and-spoke configuration. The hub-andspoke model posits polygamy as a series of dyadic relationships between the "hub" spouse (in polygyny, the husband) and each individual spoke (in polygyny, the wives). ${ }^{184}$ Admittedly, there are other possible structures for polygamous marriage, including group marriage and other variants of interrelationships. ${ }^{185}$ But many, and perhaps most, polygamist marriages in the United States fit into the hub-and-spoke model, making this a practical and logical underlying assumption. ${ }^{186}$

In addition, the proposed solutions assume that some degree of economic unity exists in polygamist marriages. This assumption may prove controversial; questions remain about whether spouses in dyadic

\footnotetext{
${ }^{183}$ See Zeitzen, supra note 15 , at 182 ("Polygamy is not a monolithic mould that people fill, but takes shape from the way people practice it. Like all societal institutions, it can be manipulated to fit the needs and purposes of its practitioners."). This variation exists, not only internationally, but between polygamists in the same social and religious groups. "There is . . the same wide variety of polygamous family patterns in today's [fundamentalist Mormon] plural marriages as there was in the nineteenth century." $I d$. at 100.

${ }^{184} I d$. at 2017.

${ }^{185}$ See, e.g., Diane J. Klein, Plural Marriage and Community Property Law, 41 Golden GATE U. L. REV. 33, 49 (2010) (“Asymmetric polygamy and group marriage would both be legal if bigamy were decriminalized, and they would probably cover a significant fraction of the actual arrangements people might desire. But they do not exhaust the possibilities. Although these two arrangements are 'scalable' for groups of four or more persons, there are also distinctive forms for larger groups.").

${ }^{186}$ See, e.g., id. at 46-47 ("This asymmetric model, when instantiated by one husband with multiple wives, is what is most commonly meant by those using the term 'polygamy.' It is the model adopted by those for whom these marriage practices have a strong customary foundation, even a religious mandate, including FLDS and independent Mormon polygamists, some Muslims, and some Africans."); Davis, supra note 3, at 1217 ("This is a radically different proposition from the way many polygamists currently practice plural marriage in the United States, conceiving it in effect as a series of legal dyads, each of which runs through the husband, like spokes around the hub of a wheel.").
} 
marriages truly split income and assets and otherwise act as an economic unit. ${ }^{187}$ Nonetheless, the evidence suggests that, while not all spouses pool all of their income, a significant portion of spouses pool at least some of their income. ${ }^{188}$ Similarly, while it is likely some polygamous spouses do not act as economic units, a significant portion pool the spouses' income (whether as dyads or collectively) and allocate it between the spouses. ${ }^{189}$ As long as the tax law treats dyadic marriages as economic units, it is difficult to justify treating polygamous marriages otherwise. Moreover, if a community property state legalized polygamous marriage, presumably the spouses' income and property would become income and property of the marital unit. In that case, the tax law would be forced to confront the appropriate taxation of polygamous families. ${ }^{190}$

The rest of this Section will present five potential ways the tax law could treat polygamous taxpayers. ${ }^{191}$ Because of the tensions inherent in a progressive tax system that looks for marriage neutrality and recognizes income pooling, ${ }^{192}$ no solution is perfect. Instead, each involves tradeoffs between competing policy goals. In analyzing the pros and cons of each regime, I conclude that a mandatory individual

${ }^{187}$ See supra notes 74-75 and accompanying text.

${ }^{188}$ See supra note 82 and accompanying text.

${ }^{189}$ Irwin Altman, Polygamous Family Life: The Case of Contemporary Mormon Fundamentalists, 1996 UTAH L. REV. 367, 389 (1996).

${ }^{190}$ Cf. I.R.S. Legal Memo. 200608038 (May 5, 2010) (holding that, in light of California's extension of community property rules to domestic partners, each partner was required to report and pay taxes on half of the community income).

${ }^{191}$ Especially in light of Professor Davis's recommendation that states base their default rules for polygamous marriage on commercial partnership law, see infra note 8 and accompanying text, it is tempting to provide a sixth possible treatment: treating polygamous spouses as a partnership or other business entity for tax purposes. But treating families as entities for tax purposes would not necessarily be fair or simple; in fact, the partnership tax rules are so complicated that "partnership tax experts expend considerable time and energy mastering" them, Bradley T. Borden, The Allure and Illusion of Partners' Interests in a Partnership, 79 U. CIN. L. REV. 1077, 1083 (2011), a heavy burden to put on individuals who just want to pay their taxes. Moreover, ultimately, individuals, not entities, pay income taxes, even where the entity is the nominal taxpayer. George K. Yin, The Taxation of Private Business Enterprises: Some Policy Questions Stimulated by the "Check-the-Box" Regulations, 51 SMU L. REV. 125, 139 (1997) ("Despite the nominal incidence of the tax on the business, some people will still pay it; we just will not know who."). Rather than solving the problems of who and how much to tax, then, imposing entity taxation would merely push those questions back one step.

192 See supra notes 17-18 and accompanying text. 
filing regime that takes familial relationships into account would provide the fairest treatment of all taxpayers. ${ }^{193}$ Given the current unlikeliness of the United States abandoning joint filing, however, I conclude that a balkanized joint filing regime would provide a secondbest solution; as long as eliminating joint filing remains politically, infeasible, balkanized joint filing constitutes the fairest and most administrable way for a joint filing system to accommodate polygamy. $^{194}$

\section{A. Refuse to Recognize Polygamous Marriage}

As one possible solution, the government could maintain the status quo, refusing to recognize polygamous spouses for tax law purposes. On its face, this would appear to be the easiest solution: among other things, it would not require any change to current practice. Under current law, a husband and wife are permitted to file a joint tax return. ${ }^{195}$ In general, the tax law recognizes as spouses couples who were married under state law as of December 31 of the year in question. ${ }^{196}$ No state currently recognizes polygamous marriages, ${ }^{197}$ meaning that, even without DOMA, polygamists could not generally file joint tax returns. ${ }^{198}$

The federal government's refusal to treat legalized polygamous relationships as marriage for tax purposes would harm polygamous families in certain ways. By treating polygamous spouses as atomized individuals, in many cases, such families' tax liabilities would not reflect the economic reality of their lives. In families where some spouses earned the majority of the family income, while other spouses

${ }^{193}$ See infra Section V.E.

${ }^{194}$ See infra Section V.D.

${ }^{195}$ I.R.C. § 6013(a) (2006).

${ }^{196}$ I.R.C. § 7703(a)(1); Toni Robinson \& Mary Moers Wenig, Marry in Haste, Repent at Tax Time: Marital Status as a Tax Determinant, 8 VA. TAX REV. 773, 79293 (1989). The tax law does not currently recognize all couples married under state law as married, however. Marriages between same-sex couples, for example, are not treated as marriage for federal tax purposes, even if such marriages are legal under state law. See supra note 150.

${ }^{197}$ Elizabeth Warner, Behind the Wedding Veil: Child Marriage As a Form of Trafficking in Girls, 12 AM. U.J. GENDER SOC. POL'Y \& L. 233, 245 (2004) ("[P]olygamy is illegal in Utah as it is in every other state.").

${ }^{198}$ In a polyganous household, where the husband and first wife had legally married, they could file a joint return. Because none of the other marriages would be recognized under state or federal law, however, none of the other wives would be eligible to file a joint return. 
earned little or no income, the family unit would be overtaxed relative to a family of the same size and income where all of the spouses earned similar amounts, violating the norm of horizontal equity.

Moreover, by refusing to recognize a state-sanctioned relationship, the tax law would reinforce the second-class nature of polygamous families. ${ }^{199}$ Even if the majority of Americans consider polygamists second-class citizens, ${ }^{200}$ their disapproval should not impact the appropriate tax treatment of such families. ${ }^{201}$

In addition, the tax law's failure to recognize polygamous relationships essentially would require polygamists to make difficult filing decisions. Because the tax law would not recognize polygamists' marriage, they would not be permitted to disregard property flows and other transactions between themselves; instead, they would need to figure out how to characterize all of the transactions between spouses over the previous year. ${ }^{202}$

The tax law's nonrecognition of polygamous marriage does not necessarily mean that no polygamous spouse could file a joint return. In many current polygamist families, the first marriage is a legal civil marriage, while subsequent marriages "are not performed by publicly authorized officials or documented in civil records." ${ }^{203}$ The initial couple, married under state law, must file tax returns as married persons, not as single persons, whether they file jointly or separately. But any subsequent spouse must file as an unmarried individual, because the subsequent marriages are not legal under state law.

Permitting one dyad to file jointly does nothing to resolve the inequities the other spouses face as a result of separate filing. Moreover, if polygamy were legal, permitting one dyad to file jointly while requiring all other spouses to file as single taxpayers would create more complexity than currently exists. If all spouses were legally married, the tax law would have to determine which dyad

\footnotetext{
${ }^{199}$ Cf. Infanti, supra note 166, at 28 ("Completing my federal income tax return reminds me that the government has singled out for condemnation my partner and me, my sister and her partner, and every other lesbian and gay man in the United States.").

${ }^{200}$ See supra note 1 and accompanying text.

201 See supra notes 150-160 and accompanying text.

${ }^{202}$ See infra notes 241-254 and accompanying text; $c f$. Infanti, supra note 199, at 28 ("In tax limbo, members of lesbian and gay couples are told what they are not (i.e., married), but they are never told what they are (and, concomitantly, how they should report transactions between them).").

${ }^{203}$ Altman \& Ginat, supra note 126 , at 131-32.
} 
could file jointly, and whether the dyad could change from year to year, or at some other periodic interval.

\section{B. Treat the Entire Polygamous Family As an Economic Unit}

Rather than refusing to recognize polygamous marriages for tax purposes, Congress could instead decide to treat all polygamous spouses as a single economic unit. ${ }^{204}$ Polygamous spouses would elect whether to file joint or separate tax returns, and would pay taxes at the same marginal tax rates as dyadic married couples.

Although the tax law does not currently permit more than two people to file a joint return, it does, in certain circumstances, treat more than two people as the appropriate and taxpaying unit. The "kiddie tax," for example, does not literally require children to file a joint return with their parents. ${ }^{205}$ However, it taxes a child's "unearned income" at her parents' top marginal tax rate if doing so would result in a higher tax liability for the child. ${ }^{206}$ Although technically the child files her own return (and, as a result, escapes joint and several liability with her parents), the tax law nonetheless treats her as being part of an economic unit with her parents for purposes of her unearned income. ${ }^{207}$

Permitting all polygamous spouses to file a joint return would provide certain benefits over ignoring polygamy altogether. Doing so would not attempt to illegitimize a relationship that one or more states had approved. It would permit polygamists to disregard transfers of property and the performance of services within the family, easing their administrative burden. And it would not present significant administrative challenges to the I.R.S. The I.R.S. would have to make minimal changes to Form 1040 - the form would need to have space for more than two spouses-but otherwise, permitting all spouses to file a joint return would not require significant alteration of currently tax law and practice.

However, nakedly treating polygamous spouses in the same manner as dyadic spouses also raises significant fairness issues. Such treatment violates the norm of horizontal equity. Horizontal equity

\footnotetext{
204 This, and any other solution that would recognize polygamy for tax purposes, would require DOMA to be repealed or amended.

${ }^{205}$ It does provide the option, however, for children to include the income that would be subject to the kiddie tax on their parents' return. I.R.C. $\S 1(\mathrm{~g})(7)(2006)$.

${ }^{206}$ I.R.C. $\$ 1(\mathrm{~g})(1)(2006)$.

${ }^{207}$ See Brunson, supra note 16, at 467.
} 
requires that similarly-situated taxpayers should be treated similarly for tax purposes. ${ }^{208}$ And, although a two-person marriage and a fiveperson marriage are both families (and, potentially, economic units), the additional three people create real differences between the two families. In 2009, the median U.S. household earned about $\$ 50,000 .^{209}$ Such a family would presumably fall into the middle class. A fiveperson marriage that also earned $\$ 50,000$, however, would have a much lower standard of living. The family would have to split the $\$ 50,000$ between five adults, rather than just two, while requiring more expenditure for basics such as food, clothing, and housing. ${ }^{210}$ Still, under this regime, the five-person polygamous family would pay approximately the same amount in taxes as the two-person family. ${ }^{211}$ Even as an economic unit, polygamous marriage differs qualitatively, and not just quantitatively, from dyadic marriage, and treating them identically does not reflect horizontal equity.

Moreover, requiring a polygamous family to file joint returns would exacerbate the secondary-earner problem. ${ }^{212}$ With a joint return, only one person's income can absorb the lower tax rates. The secondary earner pays taxes at the primary earner's top rate on her first dollar of income. With a polygamous family, the tertiary earner would then start paying taxes at the top rate of the secondary earner. Each spouse would face an increasing disincentive to work, as she had less after-tax income from her first earned dollar. Not only that: as the collective income increased, the family would begin to face phaseouts of deductions and other tax benefits, increasing the cost to the family of additional earners. ${ }^{213}$

\section{Index Tax Brackets to Family Size}

\footnotetext{
${ }^{208}$ Richard Shmalbeck, Income Averaging After Twenty Years: A Failed Experiment in Horizontal Equity, 1984 DUKE L.J. 509, 547 (1984).

209 Amanda Noss, Household Income for States: 2008 and 2009, American Community Survey Briefs 4 (2010), available at http://www.census.gov/prod/2010pubs/acsbr09-2.pdf.

${ }^{210}$ This example does not take children into account. In theory, the couple could have five children, while the polygamists have none. The tax law allows deductions for children, however, that in part offset the additional costs associate with them.

${ }^{211}$ The law could ameliorate this problem by providing a generous personal exemption available to each of the spouses.

${ }^{212}$ See supra notes 76-78 and accompanying text.

${ }^{213}$ Lawrence Zelenak, Doing Something About Marriage Penalties: A Guide for the Perplexed, 54 TAX L. REV. 1, 67 (2000).
} 
Rather than dropping polygamous taxpayers into the current dyadic brackets, Congress could redesign the tax brackets to accommodate polygamous and dyadic married taxpayers. Redesigned tax brackets could solve the horizontal equity problem ${ }^{214}$ and reduce the secondary-earner problem polygamous taxpayers would face using current brackets. ${ }^{215}$ While requiring polygamous families to use the same tax brackets as dyadic couples creates these problems, if the marginal tax brackets varied depending on the number of spouses filing jointly, the fairness analysis changes.

Varying the tax brackets based on the number of spouses would solve the horizontal equity problem. Assuming that the spouses pool their income, ${ }^{216}$ two polygamous families, each with five spouses and each with $\$ 50,000$ of annual income are similarly situated. The fact that in the first, one spouse earns the full amount, while in the second, each of the spouses earns $\$ 10,000$ does not matter. Assuming that both families act as economic units, treating them the same for tax purposes comports with the requirements of horizontal equity.

Moreover, expanding the size of the brackets based on the number of people filing jointly reduces the secondary-earner problem. Larger brackets would mean that a family could earn more income before progressing to the next marginal tax rate. While the tertiary earner still pays taxes on her first dollar of income at the secondary earner's top marginal rate, expanded brackets reduce the top tax rate paid by the secondary earner. As such, while the tertiary earner still faces some disincentive to work, she will keep a higher percentage of her after-tax income. Moreover, if this indexing to family size were carried over to deduction phaseouts, this could substantially reduce the secondary-earner problem.

However, indexing the tax brackets based on the number of spouses has its own problems. As an initial, significant impediment, Congress would need to decide how to calculate the size of the tax brackets. When first implemented, the tax brackets for married persons filing jointly were twice as large as the tax brackets for unmarried

\footnotetext{
${ }^{214}$ See supra notes 209-211 and accompanying text.

${ }^{215}$ See supra notes 212-213 and accompanying text.

${ }^{216}$ See supra notes $187-190$ and accompanying text. Although they may not actually be acting as economic units, it seems to be worth the inaccuracy to avoid the intrusive and administratively burdensome job of requiring the I.R.S. to determine (or confirm) the economics of individual families.
} 
individuals. ${ }^{217}$ In the ensuing years, however, this straightforward relationship has changed. As illustrated in Table 1, the tax brackets for a married couple filing jointly currently range from twice as large as that of an unmarried person at the lowest tax rate to the same size at the highest tax rate. ${ }^{218}$ Congress would have to determine whether to maintain these percentage differences for each additional spouse, or whether to change the indexing, a significant administrative burden. ${ }^{219}$

\begin{tabular}{|l|l|l|l|}
\hline Tax Rate & $\begin{array}{l}\text { Ceiling for an } \\
\text { Unmarried } \\
\text { Taxpayer }\end{array}$ & $\begin{array}{l}\text { Ceiling for a } \\
\text { Married } \\
\text { Taxpayer } \\
\text { Filing Jointly }\end{array}$ & $\begin{array}{l}\text { Percentage by } \\
\text { Which Married } \\
\text { Bracket } \\
\text { Exceeds } \\
\text { Unmarried }\end{array}$ \\
\hline $10 \%$ & $\$ 8,500$ & $\$ 17,000$ & $100 \%$ \\
\hline $15 \%$ & $\$ 34,500$ & $\$ 69,000$ & $100 \%$ \\
\hline $25 \%$ & $\$ 83,600$ & $\$ 139,350$ & $66.7 \%$ \\
\hline $33 \%$ & $\$ 174,400$ & $\$ 212,300$ & $21.7 \%$ \\
\hline $35 \%$ & $\$ 379,150$ & $\$ 379,150$ & $0 \%$ \\
\hline & Over $\$ 379,150$ & Over $\$ 379,150$ & $0 \%$ \\
\hline
\end{tabular}

Table 1

Moreover, indexing tax brackets to the number of spouses creates certain fairness issues. In polygamous families where one

${ }^{217}$ See supra note 54 and accompanying text.

${ }^{218}$ The highest marginal tax rate begins at the same point for married and unmarried taxpayers.

219 Even using the same percentages would not solve all of the complexity. If Congress indexed the tax brackets to the number of spouses while maintaining the same ratios as currently exist, the new brackets might look something like this:

\begin{tabular}{|l|l|l|l|l|l|}
\hline $\begin{array}{l}\text { Tax } \\
\text { Rate }\end{array}$ & Unmarried & $\begin{array}{l}\text { Two } \\
\text { Spouses }\end{array}$ & $\begin{array}{l}\text { Three } \\
\text { Spouses }\end{array}$ & $\begin{array}{l}\text { Four } \\
\text { Spouses }\end{array}$ & $\begin{array}{l}\text { Five } \\
\text { Spouses }\end{array}$ \\
\hline $10 \%$ & $\$ 8,500$ & $\$ 17,000$ & $\$ 25,500$ & $\$ 34,000$ & $\$ 42,500$ \\
\hline $15 \%$ & $\$ 34,500$ & $\$ 69,000$ & $\$ 103,500$ & $\$ 138,000$ & $\$ 172,500$ \\
\hline $25 \%$ & $\$ 83,600$ & $\$ 139,350$ & $\$ 195,122$ & $\$ 250,884$ & $\$ 306,645$ \\
\hline $28 \%$ & $\$ 174,400$ & $\$ 212,300$ & $\$ 250,090$ & $\$ 287,934$ & $\$ 325,779$ \\
\hline $33 \%$ & $\$ 379,150$ & $\$ 379,150$ & $\$ 379,150$ & $\$ 379,150$ & $\$ 379,150$ \\
\hline $35 \%$ & $\begin{array}{l}\text { Over } \\
\$ 379,150\end{array}$ & $\begin{array}{l}\text { Over } \\
\$ 379,150\end{array}$ & $\begin{array}{l}\text { Over } \\
\$ 379,150\end{array}$ & $\begin{array}{l}\text { Over } \\
\$ 379,150\end{array}$ & $\begin{array}{l}\text { Over } \\
\$ 379,150\end{array}$ \\
\hline
\end{tabular}

This table suggests a mathematical problem with indexing, however: because the 33and 35-percent brackets remain static, at seven spouses, the 28-percent tax bracket (with a ceiling of $\$ 401,469$ ) has skipped the 33-percent bracket altogether and has overlapped with the 35-percent bracket. 
spouse earned all or most of the family's income, ${ }^{220}$ increasing the size of tax brackets in relation to the number of married persons would greatly increase the marriage bonus. Although the five-spouse polygamous family where one spouse earned all $\$ 50,000$ would pay approximately the same taxes as the five-spouse polygamous family where each spouse earned $\$ 10,000$, it would pay significantly less in taxes than an unmarried individual, or a dyadic married person, who earned $\$ 50,000$.

Such a solution would also introduce additional tax-induced distortions into marriage decisions. ${ }^{221}$ Where possible, tax policymakers try to avoid causing distortions, because distortions "impose[] an otherwise avoidable welfare cost" on taxpayers. ${ }^{222}$ If Congress indexed tax brackets to the number of spouses, polygamous spouses would face tax incentives to add additional low- or no-income spouses, whether the family had a single earner or each spouse earned a similar income. Adding additional spouses would increase the size of the tax brackets under which the family calculated its tax liability. If the new spouse did not contribute any additional income, her presence as a family member would reduce the family's collective tax liability. ${ }^{223}$

Allowing polygamous families to file joint returns, whether they use the tax brackets applicable to dyadic marriage or indexed brackets, raises other issues as well. Treating all of the spouses as a single economic unit may not reflect the economic reality of a polygamous marriage. Because the structure of polygamous marriages

\footnotetext{
${ }^{220}$ Although most polygamous households need more than one person earning income, about half of the polygamous wives in Altman and Ginat's study worked roughly full-time. $I d$. at 85 . This indicates that, in at least some polygamous households, some of the spouses are not working.

221 Empirical evidence suggests that tax consequences have a measurable, statistically significant (albeit small) impact on the probability of a person's marrying. James Alm \& Leslie A. Whittington, For Love or Money? The Impact of Income Taxes on Marriage, 66 ECONOMICA 297, 299 (1999).

${ }^{222}$ Michael S. Knoll, Reconsidering International Tax Neutrality, 64 TAX L. REV. 99, 100 (2011).

${ }^{223}$ For example, using the sample indexed brackets, supra note 219 , a three-spouse polygamous family with $\$ 30,000$ of income would pay $\$ 3,225$ in taxes (i.e., 10 percent of their first $\$ 25,500$ of income plus 15 percent of their remaining $\$ 4,500$ ). If they brought in an additional spouse, however, who had no income, they would only pay $\$ 3,000$ in taxes. Of course, there may be non-tax constraints that would prevent the family from marrying another spouse, including the family's not wanting more spouses and the additional cost that they would incur in supporting another spouse.
} 
varies widely, designing a tax system that accurately reflects all polygamous families would be impossible. Still, treating a polygamous family as a single economic unit assumes that all of the spouses share property and income, and that the family functions as a conglomerate of people. If this is how state property law treats polygamous families, it may make sense to tax them collectively. But if state property law allocates ownership differently, this collective taxation may be inappropriate.

Congress would also need to address whether it would require all spouses in a polygamous family to file consistently. That is, if a five-person marriage decided to file a joint return, would all five spouses necessarily file jointly? Or could four file a joint return, with one filing a separate return? In general, it seems unlikely that one spouse would file separately. If she did, both she and the spouses filing jointly would face higher taxes. However, if she suspected that those spouses filing jointly had filed an inaccurate return, she may want to file separately to avoid joint and several liability for the tax liability. ${ }^{224}$ Permitting the same marriage to file jointly and separately, though, would add complexity to the tax system. Either solution has advantages and disadvantages but, if Congress adopts one of these solutions, it must address the question.

\section{Balkanized Filing}

Even if the tax law acknowledged polygamous marriages, Congress could structure joint filing in such a way that it continued to use two-person taxpaying units. In order to both maintain the dyadic structure of joint filing and recognize polygamous marriages, though, Congress would have to make some significant, and potentially complicated, adjustments to the current rules. As with any other tax filing regime, these changes would reflect the economics of some, but not all, polygamous marriages. No formulation of the tax law can accurately reflect all families, however. At best, the tax law can aim

\footnotetext{
${ }^{224}$ The Internal Revenue Code provides that, in some situations, an eligible spouse can be relieved from her joint and several liability for taxes. I.R.C. § 6015(a) (2006). But few spouses manage to qualify for innocent spouse relief. See, e.g., Richard C. E. Beck, The Innocent Spouse Problem: Joint and Several Liability for Income Taxes Should Be Repealed, 43 VAND. L. REV. 317, 321 (1990) ("Commentators generally agree that the innocent spouse rules are overly restrictive and foreclose relief in many deserving cases."). A polygamous spouse with any doubt about the family's tax compliance may not want to rely on the availability of such innocent spouse relief.
} 
for a regime that reflects the majority of polygamous families, notwithstanding some variation at the margins.

Many, though not all, polygamous relationships in the United States are structured in a hub-and-spoke pattern. ${ }^{225}$ In a polyganous household, this means that one man is simultaneously married to more than one woman, but the women are not married to each other. ${ }^{226}$ If the tax law assumed such a marital structure, it could treat a polygamous family as a collection of dyadic economic units, the hub spouse and each spoke spouse separately deciding whether to file jointly. Ultimately, even for polygamous families, only couples would file joint returns.

Balkanizing the polygamous family for filing purposes would permit the tax system to recognize polygamy without requiring any fundamental change to current joint filing. Although it would force square polygamous taxpayers into the circular hole of dyadic marriage, no proposal can reflect the economics of all families, let alone all polygamous families. Moreover, although balkanized filing ignores the unique qualities of the polygamous taxpayer, it validates polygamous marriage by recognizing it.

Merely dropping balkanized polygamous couples into the current joint filing world does not provide for tax justice, however. Making balkanized filing fair requires some changes to existing joint filing. Specifically, balkanized filing would have to determine how to treat the hub spouse. There are two broad ways in which a balkanized joint filing system could treat the hub spouse's income. It could require him ${ }^{227}$ to include his full income in each dyad or it could allow him to split his income between the various dyads.

Forcing the hub spouse to include his full income on each joint return he filed would be unjust. The hub spouse would pay taxes multiple times on the same income, potentially leaving him with little or no after-tax income. In fact, requiring him to include the same

\footnotetext{
${ }^{225}$ See supra notes 184-186.

${ }^{226}$ See Zeitzen, supra note 15, at 9 ("Polygyny is a form of plural marriage in which a man is permitted more than one wife."). Contrast polyganous or polyandrous marriage with group marriage, where each spouse is married to every other spouse. See id. at 13 ("Group marriage is a polygamous marriage form in which several men and women have sexual access to one another and consider themselves married to all members of the group.").

${ }^{227}$ In a polyandrous relationship, of course, the hub spouse would be a woman. But because the vast majority of polygamous relationships in the United States are polyganous, this Article refers to the husband as the hub spouse.
} 
income on several tax returns could result in his paying taxes at a rate in excess of 100 percent. ${ }^{228}$ In any event, he would pay a significantly larger percentage of his income in taxes than an unmarried individual or a person in a dyadic marriage with the same income.

The tax law could resolve this multiple taxation problem. For example, it could provide him with a tax credit for taxes paid on other returns. ${ }^{229}$ But such a solution creates other problems. The tax law would have to determine on which joint return he had to pay the tax, and on which returns he would get the credit. The dyad that did not get the credit would face a higher tax bill. While this would not violate any fairness norm if the family pooled all of its income and assets, the balkanized filing treats a polygamous family as if it only pools its assets and income in the various dyads. Thus, it treats one dyad significantly worse than it treats the others. Moreover, even if the family did pool all of its assets, presumably a balkanized joint filing regime would only impose joint and several liability between the hub spouse and the spoke spouse with whom he filed. If the hub spouse lied on his taxes, the spoke spouse with whom he did not take the tax credit would be subject to additional taxes, even if she subsequently exited the marriage. ${ }^{230}$

To avoid these problems, the tax law could, instead adjust the marginal tax brackets applicable to polygamous taxpayers. Such adjustments would be significantly different, and less administratively burdensome, however, than the adjustments necessary to index the tax brackets to the size of the family. ${ }^{231}$ Essentially, a hub spouse would

\footnotetext{
${ }^{228}$ If each dyad paid taxes at a 25 -percent rate, and the hub spouse earned $\$ 100,000$, his after-tax income would depend on how many spouses he had. With one spouse, he would pay $\$ 25,000$ and have $\$ 75,000$ of after-tax income. But, under a balkanized system that required him to include his full income on every return, with two spouses, he would have to include the $\$ 100,000$ on two tax returns, and would pay $\$ 25,000$ on each return, leaving him with $\$ 50,000$ of after-tax income. If he had four spouses, he would pay his full $\$ 100,000$ in taxes, and with five, he would owe $\$ 125,000$ of taxes on his $\$ 100,000$ of income.

${ }^{229}$ Such a tax credit could be modeled on the foreign tax credit, which provides taxpayers a credit against their U.S. income tax for foreign income taxes they paid. I.R.C. $\$ 901$ (2006).

${ }^{230}$ Christian, supra note 78, at 576 ("Under joint and several liability, . . a wife can be held liable for the tax of her former husband for tax years in which they filed jointly even if the couple has since divorced and executed a final property settlement agreement.").

${ }^{231}$ See supra Section V.C.
} 
split his income pro rata between each of his wives. ${ }^{232}$ At the same time, the applicable brackets would be multiplied by a fraction, determined by the number of returns that would be filed.

Specifically, in order to determine the tax brackets applicable to a balkanized tax return, each tax bracket would be multiplied by $(n+1) / 2 n$, where $n=$ the number of returns the polygamous family files. ${ }^{233}$ Effectively, this leaves half of the bracket the same as it would be in the case of a joint return by a non-polygamous couple. That half represents the income earned by the spoke spouse, all of which will be on the joint return in question. The other half of the tax bracket represents income of the spoke spouse, which he divides evenly between all of the spouses. The half of the bracket attributable to the spoke spouse must be divided evenly among all spouses.

To make the proposal more concrete, imagine a polyganous family with one husband, Henry, and four wives, Abby, Becky, Cathy, and Dora. In 2011, Henry has $\$ 40,000$ of taxable income. Abby has $\$ 80,000$ of taxable income, Becky has $\$ 35,000$, Cathy has $\$ 15,000$, and Dora does not earn any taxable income in 2011. The family will file four joint returns, and Henry will include $\$ 10,000$ of income on each return. Table 2 provides the 2011 tax brackets applicable to income of married taxpayers filing jointly.

\begin{tabular}{|l|l|}
\hline Income & Tax Rate \\
\hline Up to $\$ 17,000$ & 10 percent \\
\hline $\begin{array}{l}\text { Over } \$ 17,000 \text { but not over } \\
\$ 69,000\end{array}$ & 15 percent \\
\hline $\begin{array}{l}\text { Over } \$ 69,000 \text { but not over } \\
\$ 139,350\end{array}$ & 25 percent \\
\hline $\begin{array}{l}\text { Over } \$ 139,350 \text { but not } \\
\text { over } \$ 212,300\end{array}$ & 28 percent \\
\hline $\begin{array}{l}\text { Over } \$ 212,300 \text { but not } \\
\text { over } \$ 379,150\end{array}$ & 33 percent \\
\hline Over $\$ 379,150$ & 35 percent \\
\hline
\end{tabular}

\footnotetext{
${ }^{232}$ Alternatively, he could allocate his income differently between each wife, but this would create unnecessary complexity and would provide him with the ability to reduce his tax liability unfairly, allocating the most income to the wife with the least, so that no dyad paid taxes in a higher bracket than any other dyad.

${ }^{233}$ Note that $n$ will always equal the number of people in the polygamous marriage minus one. This is because the hub spouse would file a joint return with each spoke spouse, but no return by himself.
} 
Table $2^{234}$

In determining their tax liability, Henry and his family would multiply each income amount by 5/8. ${ }^{235}$ Table 3 provides the adjusted tax brackets that would apply to each of the four dyads of Henry's family. With $\$ 90,000$ of taxable income on their joint return, Henry and Abby would be in the 28-percent tax bracket. Henry and Becky, with $\$ 45,000$, would be in the 25 -percent tax bracket. Henry's and Cathy's $\$ 25,000$ taxable income would put them in the 15-percent tax bracket, and Henry's and Dora's $\$ 10,000$ of taxable income would put them in the 10-percent tax bracket.

\begin{tabular}{|l|l|}
\hline Income & Tax Rate \\
\hline Up to $\$ 10,625$ & 10 percent \\
\hline $\begin{array}{l}\text { Over } \$ 10,625 \text { but not over } \\
\$ 43,125\end{array}$ & 15 percent \\
\hline $\begin{array}{l}\text { Over } \$ 43,125 \text { but not over } \\
\$ 87,093.75\end{array}$ & 25 percent \\
\hline $\begin{array}{l}\text { Over } \$ 87,093.75 \text { but not } \\
\text { over } \$ 132,687.50\end{array}$ & 28 percent \\
\hline $\begin{array}{l}\text { Over } \$ 132,687.50 \text { but not } \\
\text { over } \$ 236,968.75\end{array}$ & 33 percent \\
\hline Over $\$ 236,968.75$ & 35 percent \\
\hline
\end{tabular}

Table $3^{236}$

This version of the balkanized tax brackets has some significant advantages over other possible ways of treating polygamous families. It, too, recognizes a state-sanctioned relationship, and does not cause the psychic harms attendant to disregarding the marriages. Moreover, it corresponds to the economics of at least some polygamous families. In addition, although the brackets must be adjusted, the adjustment is formulary, and is based on the standard brackets applicable to dyadic marriages. As such, the Treasury Department would not have to determine the appropriate tax brackets applicable to polygamous families, either initially or on an ongoing basis. And it does not double-tax any taxpayer while, at the same time, it does not permit any taxpayer to avoid paying taxes altogether.

Still, notwithstanding its advantages, this solution also presents challenges to the tax system. It clearly does not reflect the economics

\footnotetext{
${ }^{234}$ Rev. Proc. 2011-12 § 2.01, 2011-2 I.R.B. 297.

${ }^{235}$ Because they will file four returns, $n=4$. Therefore, $(n+1) / 2 n=5 / 8$.

${ }^{236}$ Rev. Proc. 2011-12 § 2.01, 2011-2 I.R.B. 297.
} 
of each polygamous family. And, while it reduces the advantages of obtaining an additional low-earning spouse, it does not eliminate them. For example, though the tax brackets shrink with every additional spouse, an additional spouse with little or no income would permit the hub spouse to cycle an additional portion of his income through the lowest marginal tax rates.

Balkanized joint filing also presents other problems, most notably what to do about transfers of property between spoke spouses. The tax law disregards transfers of property between spouses filing joint returns, because, for tax purposes, if married persons file a joint return, income to either goes on the same return and is taxed at the same rate. The same presumably would apply to transfers of property between the hub spouse and a spoke spouse. But transferring property between spoke spouses would change the taxpaying unit responsible for paying taxes on that income, and, as such, would present opportunities for tax arbitrage. Suppose that Abigail held a bond paying $\$ 100$ of interest annually. Because Abigail is in the 28-percent tax bracket, she will pay $\$ 28$ of tax on that interest, and will only have $\$ 72$ of after-tax income. If she could give her bond to Dora, the interest would only cause a $\$ 10$ tax liability, leaving $\$ 90$ of after-tax income. Without policing these intrafamilial transfers, a polygamous family could significantly reduce its tax liability.

\section{E. Mandatory Individual Filing}

The fifth potential solution would radically reconfigure the current joint filing regime. Rather than trying to shoehorn polygamous spouses into the current regime of dyadic joint filing, the tax law could shift away from joint filing altogether and replace it with mandatory individual filing. Mandatory individual tax filing means that each taxpayer, married or not, would file a tax return. On that return, she would include her income, including, among other things, wage income she earned, gains on the sale of her property, and dividends and interest on stocks and bonds she held. She would pay taxes, at her own marginal rate, on her income. If the tax law moved to a mandatory individual filing regime, all of the questions about tax bracket size and the appropriate taxpaying unit would become moot, irrespective of an individual's marital status. The tax law would not devalue polygamous marriage, because it would treat polygamous marriage in the same way it treated dyadic marriage. 
Many commentators advocate replacing joint filing with mandatory individual filing. ${ }^{237}$ Doing so, they argue, would be better for women, would make the income tax fairer between married and unmarried persons, and would not reflect outdated views on family and society. Until now, commentators have not justified individual filing by invoking polygamy, but the exercise of trying to fit polygamy into a joint filing system lends support to their argument that the joint filing system has become inadequate.

Individual tax filing presents a number of advantages over joint filing. Individual tax filing would eliminate the secondary-earner problem, because each taxpayer would take full advantage of the lower marginal rates. ${ }^{238}$ It would not assume economic unity within all marriages, ${ }^{239}$ and would not discriminate between approved economic units (e.g., dyadic heterosexual married persons) and unapproved economic units, such as domestic partners, married gay couples, and other non-traditional families. ${ }^{240}$ Moreover, individual filing provides for marriage neutrality: because single people and married people would pay taxes at the same rates, tax would not factor into the decision to enter into or to exit marriage. Additionally, for polygamous families, tax considerations would not influence decisions about whether or not to add another spouse or what level of income that additional spouse should have.

Replacing the current joint filing with mandatory individual tax filing would hurt some taxpayers, however. Individual tax filing does not treat married persons as an economic unit, in spite of the fact that many married people act with some degree of economic unity. To the extent that married persons pool their income, expenses, and assets, it would make sense to tax them as a unit, and ignoring their economic unity would tax them in a manner that did not reflect the economics of their lives. In addition, changing to individual filing would raise the taxes of families where one spouse earns significantly more than the other.

Moreover, even within an individual filing system, the tax law would need to acknowledge family relationships for some purposes. A

\footnotetext{
${ }^{237}$ See, e.g., Infanti, supra note 92, at 607; Kahng, supra note 31, at 651; Zelenak, supra note 59, at 405; Puckett, supra note 33, at 1412; Kornhasuer, supra note 75, at 109.

${ }^{238}$ See supra notes 76-78 and accompanying text.

${ }^{239}$ See supra notes 74-75 and accompanying text.

240 See supra notes 95-98 and accompanying text.
} 
pure separate filing regime would "force couples to commodify the flow of goods and services within the relationship." ${ }^{241}$ Joint filing allows married couples to ignore the informal exchanges that characterize an economically interdependent relationship. Requiring a married person to keep track of all the services and goods she provides informally to her spouse(s) would be extremely time-consuming and burdensome. $^{242}$

The burden involved in keeping track of these informal flows of services and goods extends beyond merely creating a spreadsheet to record their value. Not all flows involve transferring a portion of the paycheck, a percentage of an asset, or a service with a clear price tag. This lack of a clear valuation can create perverse incentives for a married couple where the spouses share their income and assets.

To illustrate these incentives, imagine a married couple that shares all of their income and assets evenly. The wife works as an entrepreneur, and the husband has left the paid labor market to take care of the couple's home and children. In a system with mandatory individual filing that did not take marriage into account, the tax law would necessarily treat the wife as transferring some portion of her income to her husband.

Because the tax law treats different kinds of transfers differently, the couple would need to characterize the putative transfer. For example, if the couple treated the transfer as a gift, it would not constitute gross income to the husband, and he would not pay taxes on his receipt of the gift. ${ }^{243}$ But treating the transfer of value as a gift potentially creates bad tax consequences for the couple. She cannot deduct the value of a gift, ${ }^{244}$ so she will pay taxes on the full value of her income. The couple would prefer that the husband be taxable on

${ }^{241}$ Motro, supra note 74 , at 1538.

${ }^{242}$ Admittedly, people in committed relationships that are not recognized by the tax law currently face these burdens. But the better solution would seem to be expanding the cloak of informal exchanges to these relationships rather than eliminating the cloak altogether. Professor Douglas A. Kahn proposes doing just that by taxing "only ... transactions in which the taxpayer has, either voluntarily or involuntarily, entered into a commercial transaction," and ignoring noncommercial interactions for tax purposes. Douglas A. Kahn, Exclusion From Income of Compensation for Services and Pooling of Labor Occurring in a Noncommercial Setting, 11 FLA. TAX REV. 683, 686 (2011). Of course, exempting noncommercial transactions from tax poses a "difficult question," and one which policymakers would have to address. Id. at 687.

${ }^{243}$ I.R.C. $\S 102$ (a) (2006).

${ }^{244}$ I.R.C. $§ 262$ (2006) (personal, living, and family expenses not deductible). 
some part of the income, however, because he pays taxes at a lower marginal rate than his wife.

Moreover, although the husband would not owe taxes on his receipt of the gift, her gifts may subject the wife to the gift tax. ${ }^{245}$ The gift tax provides some respite to donors, in the form of an annual exclusion and a lifetime exclusion. The wife could give up to $\$ 5$ million over the course of her life free from the gift tax. ${ }^{246}$ But the annual gift tax exclusion is much lower-in 2011 , just $\$ 13,000 .^{247}$ If, however, she earns $\$ 50,000$ in a year and constructively gives $\$ 25,000$ to her husband, she would owe a gift tax on $\$ 12,000$ a year, at rates of between eighteen and thirty-five percent. ${ }^{248}$

Alternatively, the couple could treat the transfer as payment for services. Because the tax law treats these payments differently, however, they would have to allocate the payments. Perhaps the husband helps his wife brainstorm business ideas. ${ }^{249}$ How should the couple value the brainstorming services? Under current law, provided her husband's brainstorming assistance qualifies as a business expense for the wife, she will be able to deduct her payments to him. ${ }^{250}$ Assuming he is in a lower income tax bracket than she is, and they act as an economic unit, she should value his services as highly as she can, because by shifting her income to him, they will reduce their collective tax liability. ${ }^{251}$ On the other hand, because the wife cannot deduct the value of husband's cooking, cleaning, or caring for children, ${ }^{252}$ she would be taxed on the income when she earned it, and he would be taxed on the portion of the income they allocated to cooking, cleaning, and child care. ${ }^{253}$ The couple would therefore face incentives to overvalue certain types of services and undervalue others, and would need to justify the internal dynamics of their marriage to the I.R.S. ${ }^{254}$

${ }^{245}$ See I.R.C. § 2501(a)(1) (2006) (imposition of the gift tax); I.R.C. § 2502(c) (2006) (gift tax paid by donor).

${ }^{246}$ I.R.C. $\$ \S 2505(\mathrm{a}), 2010$ (c). The $\$ 5$ million credit against the gift tax becomes a $\$ 1$ million credit in taxable years beginning after December 31, 2012. Tax Relief, Unemployment Insurance Reauthorization, and Job Creation Act of 2010, Pub. L. No. 111-312, § 304 (2010).

${ }^{247}$ I.R.C. § 2503(b) (2006); Rev. Proc. 2010-40, 2010-2 C.B. 663.

${ }^{248}$ I.R.C. $\$ 2502(a)(2)(2006)$.

${ }^{249}$ See Motro, supra note 74, at 1537.

${ }^{250}$ I.R.C. $\$ 162(a)(1)(2006)$.

${ }^{251}$ See Motro, supra note 74, at 1537-38.

${ }^{252}$ I.R.C. § 262 (2006).

${ }^{253}$ Motro, supra note 74, at 1538.

${ }^{254}$ See id. 
To reflect these dynamics, then, any mandatory individual filing regime would necessarily recognize that, in certain circumstances, taxpayers act as part of a larger economic unit. ${ }^{255}$ Discussing the actual details of such a regime goes well beyond the scope of this Article, which focuses instead on fairness as it relates to polygamy, but, nonetheless, the Article will lay out a few broad questions an individual filing regime would need to address.

First, it would need to determine what categories of taxpayers would qualify for the exceptions from pure individual taxpaying permitted by the tax law. Different commentators have suggested a range of ways to determine the appropriate economic unit. The suggestions range from permitting taxpayers to "identify their economically interdependent relationships for themselves" ${ }^{256}$ to providing the special rules to all "persons living together in economically interdependent relationships," 257 from providing some sort of income-splitting solely to married persons ${ }^{258}$ to providing this income splitting to all "economically united couples."

Although any of these proposals could produce fair results, I would propose that, at least initially, the special rules apply to relationships established under state law that include non-tax obligations. This category would include marriage, whether straight or gay, dyadic or polygamous, provided the marriage was valid under state law. It would also include domestic partnerships and civil unions recognized by a state. This proposal would not perfectly map onto the set of economically interdependent relationships; particular spouses may not act as an economic unit, while a specific cohabitating couple may share all of their income and assets equally. But state-sanctioned relationships carry with them costs and obligations-people must work to enter the relationship, and have legal obligations when it ends.

\footnotetext{
${ }^{255}$ See, e.g., id. at 1540 ("This brings us to the most compelling and internally consistent justification - or, to be precise, the true cultural explanation-for income splitting. When husbands and wives share income, we are most comfortable viewing each spouse's efforts as 'by and for' the marital unit.").

${ }^{256}$ See Infanti, supra note 92, at 647.

257 See LAW COMM'N OF CAN., Beyond CONJugality: ReCOGNIZING AND SupPorting Close Personal AdUlt Relationships 89 (2001), available at http://www.samesexmarriage.ca/docs/beyond_conjugality.pdf.

${ }^{258}$ See Bittker, supra note 20, at 1421. Professor Bittker was referring solely to dyadic married couples, of course, but there is no reason this could not be expanded to polygamous married persons.

${ }^{259}$ See Motro, supra note 74, at 1559.
} 
These non-tax costs and obligations provide prima facie evidence of a relationship entered into for other than (or at least more than) tax purposes, without requiring an invasive inquiry into the actual facts of the relationship. ${ }^{260}$

After determining what relationships will qualify for the exceptions from purely individual taxpaying, we must determine what exceptions the tax law will permit. For instance, should the tax law permit married persons, domestic partners, and civil unions to split their income on their separate returns? Doing so would seem to negate the purpose behind individual filing by eliminating marriage neutrality.

On the other hand, permitting members of an economic unit to transfer goods or perform services for one another without tax consequences would cause individual filing to better comport with taxpayers' assumption of economic unity within altruistic relationships. It would also eliminate the recordkeeping burden on the taxpayers and eliminate the threat of an invasive I.R.S. audit of the internal dynamics of the relationship.

In addition, because each person would file her return and pay taxes separately, the tax law would need to provide rules for determining who could claim deductions for children and other dependents. ${ }^{261}$ It would need to provide rules for determining how to allocate other deductions currently available to married persons, especially those relating to shared property such as the mortgage interest deduction. ${ }^{262}$ It would also need to determine whether a

\footnotetext{
260 Admittedly, such a standard is both over- and under-inclusive. But no administrable and politically-acceptable proposal can perfectly capture just those relationships that are economically interdependent without capturing some relationships that are not interdependent or without ignoring some that are interdependent.

${ }^{261}$ Under current law, if parents are divorced, the parent with whom the child resides for the longest period of time can claim the dependency deduction. I.R.C. $\S 152$ (c)(4)(B)(i) (2006). With separate filing, though, the child could live with both parents for the same amount of time. In the case of divorced parents, where a child lives with both parents for the same period of time, the parent with the highest adjusted gross income takes the deduction. I.R.C. § 152(c)(4)(B)(ii). That would appear to be a good solution in the case of separate filing.

${ }^{262}$ I.R.C. $§ 163(\mathrm{~h})(2)(\mathrm{D})$ (2006). Specifically, if the spouses pool their income, and use such pooled income to pay the mortgage, should only one spouse take the deduction, should they evenly split the deduction, should they split it pro rata according to their income, or should they split it in some other manner? Pro rata according to their income would seem to make sense, but the law would have to address the question.
} 
taxpayer who paid a deductible expense on behalf her spouse could take deduction for such payment. ${ }^{263}$

Moreover, the tax law would also need to provide anti-abuse rules. Under current law, as under the proposed regime, the tax law ignores transfers of property between spouses. Under current law, ignoring such transfers between spouses filing jointly makes sense: no matter who owns the property, they must include any income it produces, or any gains from its sale, on their joint return. In a separate return world, however, absent an anti-abuse rule, a high-income spouse could transfer income-producing property to a low-income spouse and, by doing so, reduce their collective tax liability. ${ }^{264}$ They could similarly reduce the tax on capital gains by transferring appreciated property from a high-income spouse to a low-income spouse, or increase the value of loss deductions be doing the reverse. In order to prevent this, the tax law would need the ability to reallocate some income or gains to the donor spouse.

\section{CONCLUSION}

Although recently polygamy has received increased scholarly attention, that attention has largely focused on the questions of whether states should decriminalize, or even legalize, polygamous marriage, and how such marriage should function. They have largely ignored other law in their analysis. Professor Davis has begun to shift the debate, however, to second-generation questions about the contours of a legalized polygamy. This Article has taken up the essential second-generation question of how polygamists should pay taxes. The answer is not obvious-polygamous marriage differs both quantitatively and qualitatively from dyadic marriage.

For example, polygamous families do not fit into the framework of current tax law. The tax law treats heterosexual married couples as an appropriate taxpaying unit, but its treatment of dyadic married persons provides no obvious clue as to the appropriate

\footnotetext{
${ }^{263}$ For example, under current law, a taxpayer can deduct medical expenses paid on her own behalf or on behalf of her spouse or dependent to the extent those expenses exceed 7.5 percent of her adjusted gross income. I.R.C. § 213(a) (2006). In a separate filing world, Congress would need to determine whether she could continue to deduct payments made on behalf of her spouse and, if she could, if payments in excess of 7.5 percent of her adjusted gross income would suffice (which could drastically increase the amount of the deductible expense) or if appropriate adjusted gross income would also include her spouse's income.

${ }^{264} \mathrm{Cf}$. Brunson, supra note 16, at 463.
} 
treatment of polygamous married persons. But as soon as the first state legalized polygamous marriage, polygamous families would need to know how the tax law applied to them. ${ }^{265}$ Before polygamy becomes legal, then, we need to determine how polygamists will fit into these legal regimes. In spite of its importance, though, this Article is the first to address the appropriate tax treatment of polygamous taxpayers.

Polygamy and tax presents a chicken-and-egg problem, however. Although the state needs to know how polygamists will pay their taxes in order to smoothly transition into legalized polygamy, knowing the legal contours of polygamous marriage would help to create a tax regime that accurately reflected the economics of polygamous marriage. As a result, this Article has evaluated five possible ways that the tax law could treat polygamy, irrespective of the economics of a polygamous family.

Even without state-sanctioned polygamy, however, the analysis of how the tax law could take account of polygamy undermines the basis of the current joint filing regime. While there is no single "correct" way to tax married persons, ${ }^{266}$ joint filing appears to be unworkable in a world of expanded familial options. Commentators have demonstrated that the joint return makes possibly unwarranted assumptions about the economic unity of marriage, that joint filing may harm women, and that joint filing is unfair to the many people who cannot file jointly. This Article goes beyond those objections to demonstrate that, in order to accommodate non-dyadic relationships, Congress would need to make significant, complex changes to joint filing. And the necessary changes may be difficult, if not impossible, to design and implement.

As a result, the thinking about polygamy adds more weight to the argument that the United States should move to mandatory individual tax filing, albeit an individual filing that takes account of familial relationships. Individual filing removes the need to adjust tax brackets to achieve horizontal equity and fairness. It eliminates the secondary-earner problem that polygamy magnifies in any version of joint filing. And it eliminates the tax incentive for a family adding more spouses. Still, as discussed above, given the importance of

\footnotetext{
${ }^{265}$ To some extent, this assertion rests on the assumption that Congress repeals or the courts reject DOMA.

${ }^{266}$ Zelenak, supra note 59, at 404-05 ("There is no absolutely right or wrong way to tax married couples. A system that is right for one time and place may be wrong for another.").
} 
marriage and family, even mandatory individual filing would necessarily make allowances for familial relationships, both in recognition of the unselfish behavior that often characterizes family and in order to provide some amount of privacy.

In spite of the growing evidence in favor of mandatory individual filing, however, most commentators believe that the tax law will continue to permit married couples to file jointly for at least the near future. To the extent Congress has not adopted mandatory individual tax filing when polygamy becomes legal, however, the tax law will have to have a fallback position. Of the possible solutions discussed in this paper, balkanized filing appears to be the next-best option. Although it, too, creates complexity, requiring tax brackets tailored to the size of the polygamous family, the tailored brackets are determined mechanically and require no additional input from the Treasury Department. Moreover, because it would treat similarlysituated families in the same way, it appears to conform with horizontal equity considerations. Although the secondary-earner problem still exists and a polygamous family could reduce its tax liability by adding an additional low-income spouse, balkanized filing minimizes these problems to the extent possible. 